\title{
Akademik Alan Memnuniyeti, Öz-Yeterlik ve Kontrol Odağının Kopya Çekmeye Yönelik Tutumun Yordayıcıları Olarak İncelenmesi ${ }^{1}$
}

\author{
Arş. Gör. Fatma Zeynep SAYLIK* \\ Dicle Üniversitesi, Edebiyat Fakültesi, Psikoloji Bölümü, Diyarbakır / Türkiye \\ fzeynepsaylik@gmail.com, ORCID: 0000-0002-4787-5969
}

\author{
Prof. Dr. Altay EREN
}

Bolu Abant İzzet Baysal Üniversitesi, Eğitim Fakültesi, Eğitim Bilimleri Bölümü, Bolu / Türkiye eren_a@ibu.edu.tr, ORCID: 0000-0001-8964-2082

Doç. Dr. Meral GEZİCİ-YALÇIN

Bolu Abant İzzet Baysal Üniversitesi, Fen-Edebiyat Fakültesi, Psikoloji Bölümü, Bolu / Türkiye meralgeziciyalcin@ibu.edu.tr, ORCID: 0000-0002-8751-3428

\section{$\ddot{O} z$}

$\mathrm{Bu}$ araştırmanın ilk amacı üniversite öğrencilerinin alan seçiminden duydukları memnuniyet, akademik öz-yeterlik inançları, akademik kontrol odakları ve kopya çekmeye yönelik tutumları arasındaki ilişkilerin incelenmesidir. İkincisi ise, üniversite öğrencilerinin alan seçiminden duydukları memnuniyet ile kopya çekmeye yönelik tutumları arasındaki ve akademik öz-yeterlik inançları ile kopya çekmeye yönelik tutumları

\footnotetext{
${ }^{1} \mathrm{Bu}$ çalışma III. Sosyal Psikoloji Kongresi'nde sözlü bildiri olarak sunulmuştur.

* Sorumlu Yazar. Tel: +90 (412) 2411000 (8212)

Makale Tarih Bilgisi. Gönderim: 27.04.2020, Kabûl: 01.06.2020, Basım: Haziran, 2021.

(C) 2021. Kalem Eğitim ve Sağlık Hizmetleri Vakfı. Bütün Hakları Saklıdır. ISSN: 2146-5606, e-ISSN: 2687-6574.
} 
arasındaki ilişkilerde, akademik kontrol odağının aracı rolünün sorgulanmasıdır. Araştırmanın örneklemini, Türkiye'nin Batı Karadeniz bölgesindeki büyük bir üniversitenin farklı fakültelerinin çeşitli bölümlerinde öğrenim gören 715 öğrenci $(\mathrm{K} 1 \mathrm{Z}=452$; Erkek=263) oluşturmuştur. Araştırmada açımlayıcı ilişkisel desen kullanılmış ve bu doğrultuda, gizil değişkenler korelasyon analizi ile yapısal eşitlik modellemesi analizleri gerçekleştirilmiştir. Bulgular, akademik alan memnuniyetinin ve akademik öz-yeterlik inancının hem dışsal akademik kontrol odağıyla hem de kopya çekmeye yönelik tutumla anlamlı düzeyde ve negatif yönde ilişkilendiğini göstermiştir. Bulgular, dışsal akademik kontrol odağının hem akademik alan seçiminden duyulan memnuniyetle kopya çekmeye yönelik tutum arasında hem de akademik öz-yeterlik inançlarıyla kopya çekmeye yönelik tutum arasında tam aracı rolü oynadığını da göstermiştir. Öğrencilerin alan seçimlerinden dolayı duydukları memnuniyetin, akademik anlamda sahip olduklarına inandıkları yeterliğin ve akademik açıdan elde ettikleri sonuçları içsel ya da dışsal referanslara atıfla açıklamalarının, kopya çekmeye yönelik tutumlarıyla seçici biçimde ilişkilendiği sonucuna ulaşılmıştır. Araştırmada, eğitim bilimsel doğurgular ve gelecekte yapılabilecek araştırmalar da tartışılmıştır.

Anahtar Kelimeler: Kopya çekmeye yönelik tutum; Akademik alan memnuniyeti; Akademik öz-yeterlik; Akademik kontrol odağı; Aracılık analizi.

\title{
Investigating the Satisfaction with Academic Major Choice, Self-Efficacy, and Locus of Control as Predictors of Attitudes towards Cheating
}

\begin{abstract}
The first aim of the study was to examine the relationships among undergraduate students' satisfaction with academic major choice, academic self-efficacy, academic locus of control, and attitudes towards cheating. Second, we investigated the mediating roles of academic locus of control in the relationships between undergraduate students' satisfaction with academic major choice and attitudes towards cheating, as well as in the relationships between their academic self-efficacy and attitudes towards cheating. The sample consisted of 715 undergraduate students $($ Female $=452$; Male $=263$ ), majoring in diverse fields of study in different faculties at a large university located in the Western Black Sea Region of Turkey. An exploratory correlational design was used in the study and in line with this, a latent-factor correlational analysis and the structural equation modeling analyses were conducted. The results showed that satisfaction with academic major choice and academic selfefficacy were significantly and negatively related to both external academic locus of control and attitudes towards cheating. The results also demonstrated that external academic locus of control fully mediated
\end{abstract}


both the relationship between satisfaction with academic major choice and attitudes towards cheating as well as the relationship between academic self-efficacy and attitudes towards cheating. It was concluded that undergraduate students' satisfaction with their academic major choice, academic competence they believe that they have, and explaining academic outcomes that they achieved by referring to internal or external frames of references were selectively related to their attitudes towards cheating. Implications for education and directions for further studies were also discussed in the study.

Keywords: Attitude towards cheating; Satisfaction with academic major choice; Academic self-efficacy; Academic locus of control; Mediation analysis.

\section{Extended Summary}

Academic cheating is a typical unethical behavior that is frequently observed at schools. For example, it was reported that $55 \%$ and $84 \%$ of the students in the United States and Poland respectively, cheat academically (Lupton, Chapman and Weiss, 2000). In Turkey, this ratio varies from 65\% to $85 \%$ among students (Polat, 2017) in general, undergraduate students (e.g., Lüle-Mert, 2012) and pre-service teachers (e.g., Bozdoğan and Öztürk, 2008) in particular. Thus, considerable research examines the underlying factors leading students to academic cheating (e.g., Polat, 2017). The results of these studies indicate that individual difference variables such as satisfaction with academic major choice, academic self-efficacy, and academic locus of control play important roles in students' attitudes towards cheating (e.g., Sagone and De Caroli, 2014). Intriguingly, the relationships between these variables have not been examined in a single study to date. Likewise, the mediating roles of academic locus of control in the mentioned relationships have not also been addressed. However, examining the relationships between the aforementioned variables could provide a larger framework within which factors associating with students' attitudes towards cheating are discernible. In turn, this framework could provide a solid basis for educational and curricular attempts aiming to increase students' ethical sensitivity to academic cheating. Indeed, such a framework is particularly important for students who enroll in tertiary education programs because they are at the initial phase of their career (i.e., university education).

\section{Purpose}

The aim of the study was twofold. The first aim was to examine the relationships among undergraduate students' satisfaction with academic major choice, academic self-efficacy, academic locus of control and attitudes 
towards cheating. The second one was to investigate the mediating roles of academic locus of control in the relationships between undergraduate students' satisfaction with academic major choice and attitudes towards cheating, as well as in the relationships between their academic self-efficacy and attitudes towards cheating.

\section{Method}

A total of 715 undergraduate students (Female $=452$; Male=263), majoring in diverse fields of study in different faculties at a large university located in the Western Black Sea Region of Turkey, voluntarily participated in the study. The data were collected during the autumn semester of the 2018/2019 academic year by the first author of the article through the Attitude Towards Cheating Scale (Ay and Çakmak, 2015), Satisfaction with Academic Major Scale (Nauta, 2007), Academic Self-Efficacy Belief Scale (Y1lmaz, Gürçay and Ekici, 2007), and Academic Locus of Control Scale (Akın, 2007). Research instruments were presented to the participants with instructions regarding the aim of the study and a brief explanation about how to respond to items in the scales. The administration process lasted approximately 20 minutes. The study was approved by the Institutional Review Board of the university where the present study was carried out.

\section{Results}

The results of the latent-factor correlation analysis demonstrated that satisfaction with academic major choice and academic self-efficacy were significantly and negatively related to both external academic locus of control and attitudes towards cheating. The results of the SEM analyses revealed that the structural model in which academic self-efficacy and satisfaction with academic major choice predicted attitudes towards cheating through external academic locus of control, had better fit to the data $\left(\chi^{2}(716)=1556.26\right.$; CFI $=.935$; $\mathrm{TLI}=.929$; $\mathrm{RMSEA}=.041$; $\mathrm{SRMR}=.055)$ than the alternative model in which the mediating role of external academic locus of control was not considered $\left(\chi^{2}(719)=1780.18 ; \quad\right.$ CFI $=.918 ; \quad$ TLI $=.911 ; \quad$ RMSEA $=.045 ; \quad$ SRMR $=.094 ;$ $\left.\Delta \chi^{2}(\Delta \mathrm{sd}=3)=223.92, p<.001\right)$.

\section{Discussion}

The results showed that the satisfaction with academic major choice and academic self-efficacy were significantly and negatively related to both external academic locus of control and attitudes towards cheating. The results of the latent-factor correlation analysis were in line with the studies in which the 
relationships between the research variables were examined in a piecemeal manner (e.g., Huebner, Ash and Laughlin, 2001). Therefore, these results can be reasonably explained as students who are more satisfied with their academic major choice and have high academic self-efficacy are less likely to explain academic outcomes that they have achieved by referring to the external factors (e.g., luck) and are less tolerant towards academic cheating, or vice versa. More importantly, the results of the SEM analysis revealed that the external academic locus of control fully mediated both the relationship between satisfaction with academic major choice and attitudes towards cheating as well as the relationship between academic self-efficacy and attitudes towards cheating (for a similar result, see Yeşilyurt, 2014). This result clearly highlighted the fact that the relationships between satisfaction with academic major choice, academic self-efficacy, and attitudes towards cheating were not straightforward. Hence, this result can be reasonably interpreted as being more satisfied with the academic major choice and having high academic self-efficacy are not sufficient conditions to be less tolerant towards academic cheating unless explaining academic outcomes by referring to the external factors to a lesser extent.

\section{Conclusion}

Two major conclusions can be derived from the current results. First, undergraduate students' satisfaction with their academic major choice, academic competence they believe that they have, and explaining academic outcomes that they achieved by referring to internal or external frames of references were selectively related to their attitudes towards cheating. Second, the negative associations of undergraduate students' attitudes towards cheating with their satisfaction with academic major choice and academic competence they believe that they have, entirely depended on explaining academic outcomes that they achieved by referring to an external frame of reference to a lesser extent. The results of the study have important implications for educational and curricular attempts targeting to increase undergraduate students' ethical sensitivity to academic cheating. Nevertheless, these results should cautiously be interpreted due to the several limitations such as small sample size and correlational design which limits the generalizability of the current results and strictly prohibits causal inferences regarding the relationships between the research variables respectively, each of which provides a solid basis for further investigations. 


\section{Giriş}

Kopya çekme, okul gibi akademik ortamlarda oldukça yaygın bir usulsüzlük biçimidir (Ledesma, 2011; McCabe, Trevino ve Butterfield, 2001; McCabe, Feghali ve Abdallah, 2008). Nitekim Kuzey Amerika'da ve Kanada'da her beş üniversite öğrencisinden birinin sınavlarda kopya çektiği rapor edilmiştir (McCabe, 2005). Ayrıca, Amerika Birleşik Devletleri'ndeki üniversite öğrencilerinin \%55'inin, Polonya'daki öğrencilerin ise \%84'ünün kopya çektiği de belirtilmiştir (Lupton, Chapman ve Weiss, 2000). Benzer biçimde, Tayvan'daki üniversite öğrencilerinin \%61'inin, öğrenim gördükleri süre içerisinde en az bir kez akademik usulsüzlüğe başvurdukları rapor edilmiştir (Lin ve Wen, 2007). Söz konusu bulgulara ek olarak, İran'daki öğrencilerin yaklaşık \%36'sının kopya çekmeyi normal karşıladığı da saptanmıştır (Ahmadi, 2012). Türkiye'deki öğrencilerin ise \%65-85 arasında değişen oranlarda kopya çektikleri ifade edilmektedir (Polat, 2017). Üstelik görece yakın bir geçmişte Türkiye'de gerçekleştirilen araştırmalardan elde edilen bulgular, kopya çekmenin üniversite öğrencileri arasında olduğu kadar (Lüle-Mert, 2012; Semerci, 2004), öğretmen adayları arasında da kabul edilebilir bir davranış olarak algılandığını göstermiştir (Bozdoğan ve Öztürk, 2008; Durmuşçelebi, 2011; Eraslan, 2011; Özden, Özden-Özdemir ve Biçer, 2015; Ünlü ve Eroğlu, 2012; Yangın ve Kahyaoğlu, 2009).

Yukarıda yapılan açıklamalar doğrultusunda, kopya çekme davranış1nın Türkiye'deki üniversitelerde de yaygın olan ya da üniversite öğrencileri tarafından kabul edilebilir bir davranış biçimi olarak algılanan önemli bir problem durumu olduğu belirtilebilir. Öğrencilerin kopya çekme davranışlarının gözlenmesinin ve/veya onları kopya çekmeye yönlendirecek herhangi bir müdahalede bulunmanın etik gerekçelerden dolayı mümkün olmaması nedeniyle, konuyla ilgili alanyazındaki araştırmalar büyük ölçüde ilişkisel desenlere dayalı olarak gerçekleştirilmiştir (bkz. Çetin, 2007; Er ve Gürgan, 2011). Ayrıntılı olarak, bu araştırmalarda öğrencilerin kopya çekme davranışlarını benimseme eğilimlerinin önemli göstergeleri olan kopya çekmeye yönelik algılarının ve/veya tutumlarının incelenmesine odaklanılmıştır (Ahmadi, 2012; Çetin, 2007; Eraslan, 2011; Kerkvliet ve Sigmunt, 1999; Polat, 2017). Söz konusu etik gerekçelerin oluşturduğu sınırlılık bu araştırma için de geçerlidir. Dolayısıyla, yukarıda değinilen problem durumuna ilişkin olarak bu araştırmada öğrencilerin kopya çekmeye yönelik davranışlarına değil, tutumlarına odaklanılmıştır. 
Kopya çekmenin olası nedenlerinin incelendiği araştırmalar, öğrencilerin öğrenim gördükleri alanlardaki dersleri ilgi çekici olarak algılamamaları ve/veya sevmemelerinin, kopya çekmeye yönelik tutumlarıyla ilişkilenen (Bozdoğan ve Öztürk, 2008) önemli bir unsur olduğunu göstermiştir. Esasen bir dersi sevme ya da onu ilgi çekici olarak algilama akademik alan seçiminden duyulan memnuniyetin önemli bir göstergesi olarak değerlendirilebilir (Benmansour, 2000). Buna karşın, akademik alan seçiminden duyulan memnuniyetin kopya çekmeye yönelik tutumla ilişkisi az sayıda araştırmaya konu olmuştur. Üstelik bu araştırmalardan elde edilen bulgular, kopya çekmeye yönelik tutumun akademik alan seçiminden duyulan memnuniyetle hem negatif (Soytürk, Tepeköylü-Öztürk, Topuz ve Yetim, 2015) hem de pozitif yönde ilişkilenebildiğini (Çetin 2007) de göstermiştir. Bu çelişki, akademik alan seçiminden duyulan memnuniyetin kopya çekmeye yönelik tutumla olan ilişkisinde aracı rolü oynama potansiyeli içeren değişkenlerin, söz konusu araştırmalarda dikkate alınmamasından kaynaklanmış olabilir. Dolayısıyla bu noktada, akademik kontrol odağının söz konusu ilişkide önemli bir aracı değişken rolü oynama potansiyelinden söz edilebilir. Daha açık bir ifadeyle, bir öğrencinin akademik başarısının nedenini nasıl algıladığının; başka bir deyişle, başarısını içsel (çaba vb.) ya da özellikle dışsal (sınav sorularının çok zor olduğunu ve/veya dersin öğretim elemanının kendisinden hoşlanmadığını düşünme vb.) unsurlara dayalı olarak açıklamasının, öğrenim gördüğü alandan duyduğu memnuniyetle kopya çekmeye yönelik tutumu arasındaki ilişkide aracı rolü oynama potansiyeli içerdiği söylenebilir. Nitekim konuyla ilgili alanyazında, akademik kontrol odağı daha çok dışsal olan öğrencilerin kopya çekme eğilimlerinin, akademik kontrol odağ daha çok içsel olan öğrencilere göre, anlamlı düzeyde daha yüksek olduğu rapor edilmiştir (Alarape ve Onakoya, 2003; Büyükgöze, 2017; Pino ve Smith, 2003).

Öğrencilerin kopya çekmeye yönelik tutumlarıyla anlamlı düzeyde ve seçici biçimde ilişkilenme potansiyeli bulunan diğer bir değişken ise akademik öz-yeterlik inançlarıdır. Alanyazında öğrencilerin genel öz-yeterlik inançlarının etik dışı davranışlarıyla orta düzeyde ve negatif yönde ilişkilendiğinin saptanmış olması (Büyükgöze, 2017; Permatasari, 2017), bu öngörüyü destekler niteliktedir. Ancak Er ve Gürgan'ın (2011) çalışmasında öğretmen adaylarının öz-yeterlik algıları ile kopya çekme tutumları arasında zayıf ve pozitif yönlü bir ilişki saptanmıştır. Söz konusu zayıf ve pozitif yönlü ilişki, öğrencilerin öz-yeterlik inançlarının gerçekçi olmamasından (Kruger ve Dunning, 1999) ya da daha önemlisi, akademik kontrol odağının kopya çekmeye 
yönelik tutum üzerindeki etkisinin kontrol edilmemesinden kaynaklanmış olabilir. Nitekim bir öğrencinin herhangi bir konuya ilişkin öz-yeterlik inancının güçlü olması, o konuda elde ettiği başarıyı ya içsel ya da dışsal kontrol odağına yönelik olarak açıklayacağının temel bir göstergesi olarak algılanmamalıdır. Üstelik değinilen araştırmada söz konusu ilişkinin zayıf olduğunun saptanmas1 (Er ve Gürgan, 2011); diğer araştırmalarda ise (Büyükgöze, 2017; Permatasari, 2017), öz-yeterlik inançlarının akademik bir usulsüzlüğe yönelik eğilimi yansıtan kopya çekmeye yönelik tutumla ilişkilenme potansiyeli, genel içeriğe sahip öz-yeterlik inançlarına kıyasla daha belirgin olan akademik öz-yeterlik inançları bağlamında incelenmemiş olması, bu konuda kesin bir çıkarımda bulunmanın doğru olmadığına işaret etmektedir. Bu nedenle, araştırmada öğrencilerin genel öz-yeterlik inançları değil, akademik öz-yeterlik inançları dikkate alınmıştır.

Önemli olarak, konuyla ilgili alanyazında, akademik öz-yeterlik inançlarıyla akademik içsel kontrol odağı arasında anlamlı düzeyde ve pozitif yönde bir ilişkinin saptanması (Sagone ve De Caroli, 2014) ve kopya çekmeye yönelik tutumun akademik içsel kontrol odağı ile anlamlı düzeyde; ancak negatif yönde, akademik dışsal kontrol odağı ile de pozitif yönde ilişkilendiğinin gözlenmesi (Alarape ve Onakoya, 2003; Büyükgöze, 2017; Coleman ve Mahaffey, 2000; Gallagher, 2010; Pino ve Smith, 2003), akademik kontrol odağının, akademik öz-yeterlik inançlarıyla kopya çekmeye yönelik tutum arasında aracı rolü oynama potansiyeli içerdiğine işaret etmektedir. Dolayısıyla, bu araştırmada akademik kontrol odağının, akademik öz-yeterlik inançlanıla kopya çekmeye yönelik tutum arasındaki olası aracı rolüne de odaklanılmıştır.

Yukarıda yapılan açıklamalar ve değinilen araştırmalar doğrultusunda, öğrencilerin kopya çekmeye yönelik tutumlarıyla ilişkilenme potansiyeli içeren birçok değişken olduğu ve bu değişkenler arasında özellikle akademik alan seçiminden duyulan memnuniyet, akademik öz-yeterlik inançları ve akademik kontrol odağının, öğrencilerin kopya çekmeye yönelik tutumlarının açıklanmasındaki rollerinin belirgin olduğu öne sürülebilir. Ancak konuyla ilgili alanyazında, akademik alan seçiminden duyulan memnuniyet, akademik özyeterlik inançları ve akademik kontrol odağının, öğrencilerin kopya çekmeye yönelik tutumlarıyla olan ilişkilerinin aynı araştırma kapsamında ve bir arada incelendiği bir araştırmaya rastlanmamıştır. Oysa böyle bir araştırma üç nedenden dolayı önemlidir.

Birincisi, alan seçiminden duyulan memnuniyet, akademik öz-yeterlik 
inançları ve akademik kontrol odağının, öğrencilerin kopya çekmeye yönelik tutumlarıyla nasıl ilişkilendiklerinin incelenmesi, bu değişkenlerin, kopya çekme gibi oldukça yaygın bir akademik usulsüzlüğün nedenlerinin aydınlatılmasına katkı sağlayarak, kopya çekmeye yönelik davranışların engellenmesine/azaltılmasına yönelik girişimler için kapsamlı ve güvenilir bir kuramsal çerçeve sağlayabilir.

İkincisi, bundan önceki araştırmalardan farklı olarak, bu araştırmada alan seçiminden duyulan memnuniyet, akademik öz-yeterlik inançları ve akademik kontrol odağının kopya çekmeye yönelik tutumla ilişkilerinin bir arada incelenmesi, söz konusu değişkenlerin kopya çekmeye yönelik tutumla olan ilişkilerinin gücünü ve yönünü açığa çıkararak, üniversitelerin mevcut öğretim programlarında, öğrencilerin kopya çekmeye yönelik davranışların azaltılması amacıyla hangi bireysel farklılık değişkenlerine öncelikle yer verilmesi gerektiğine ilişkin tartışmalar/öneriler için sağlam bir zemin oluşturabilir.

Üçüncüsü, bu araştırmada, alan seçiminden duyulan memnuniyetle kopya çekmeye yönelik tutum ve akademik öz-yeterlik inançlarıla kopya çekmeye yönelik tutum arasındaki ilişkilerde akademik kontrol odağının aracı rollerine de odaklanılması, akademik kontrol odağının söz konusu ilişkilerdeki aracı rollerinin karşılaştırmalı bir bakış açısıyla sorgulanmasına imkân vererek, bundan önceki araştırmalarda elde edilen çelişkili bulguların aydınlatılmasına katkıda bulunabilir.

Dolayısıyla, bu araştırmada akademik alan seçiminden duyulan memnuniyet, akademik öz-yeterlik inanc1, akademik kontrol odağı ve kopya çekmeye yönelik tutum arasındaki ilişkilerin incelenmesine odaklanılmıştır. Esasen bu araştırmanın iki amacı bulunmaktadır. Birincisi, üniversite öğrencilerinin alan seçiminden duydukları memnuniyet, akademik öz-yeterlik inançları, akademik kontrol odakları ve kopya çekmeye yönelik tutumları arasındaki ilişkilerin incelenmesidir. İkincisi ise, üniversite öğrencilerinin alan seçiminden duydukları memnuniyet ile kopya çekmeye yönelik tutumları arasındaki ve akademik öz-yeterlik inançları ile kopya çekmeye yönelik tutumları arasındaki ilişkilerde, akademik kontrol odağının aracı rolünün sorgulanmasıdır. Konuyla ilgili alanyazında, söz konusu değişkenlerin bütüncül bir bakış açısıyla incelendiği araştırmanın bulunmaması ve kopya çekmeye yönelik tutumla bu araştırmada odaklanılan değişkenlerden bazıları (örneğin akademik öz-yeterlik inançları) arasında çelişkili bulguların elde edilmesiyle spesifik hipotezler sınırlı tutulmuş, üç ayrı şekilde kapsamlı araştırma sorusu 
oluşturulmuştur. Bu sorular ve ilgili hipotezler şunlardır:

1. Üniversite öğrencilerinin akademik alan seçiminden duydukları memnuniyet, akademik öz-yeterlik inançları, akademik kontrol odakları ve kopya çekmeye yönelik tutumları arasında anlamlı ilişkiler var mıdır? Söz konusu araştırma sorusu kapsamında aşağıdaki hipotezler oluşturulmuştur:

$\mathrm{H}_{1}=$ Akademik dişsal kontrol odağı ile kopya çekmeye yönelik tutum arasında pozitif yönlü ve anlamlı ilişki vardır.

$\mathrm{H}_{2}=$ Akademik içsel kontrol odağı ile kopya çekmeye yönelik tutum arasında negatif yönlü ve anlamlı ilişki vardır.

2. Üniversite öğrencilerinin akademik öz-yeterlik inançları, akademik alan seçiminden duydukları memnuniyet ve akademik kontrol odakları, kopya çekmeye yönelik tutumlarını anlamlı düzeyde yordamakta mıdir?

3. Üniversite öğrencilerinin akademik kontrol odakları, akademik öz-yeterlik inançları ile kopya çekmeye yönelik tutumları arasındaki ve akademik alan seçiminden duydukları memnuniyet ile kopya çekmeye yönelik tutumları arasındaki ilişkilerde, anlamlı aracı rolleri oynamakta midir?

\section{Kopya Çekmeye Yönelik Tutum}

Kopya çekme, belirli bir kültüre veya coğrafyaya özgü olmayan ancak sosyokültürel bağlamda farklı şekillerde algılanabilen karmaşık bir davranış biçimi olarak değerlendirilebilir (Starovoytova ve Namango, 2016). Kopya çekmenin bu özelliği, onun ne olduğu ve hangi davranışların kopya çekme olarak değerlendirileceği gibi sorulara ilişkin yanıtları da karmaşık hâle getirmektedir (Roig ve DeTommaso, 1995). Nitekim konuyla ilgili alanyazında, kopya çekmenin üzerinde uzlaşılmış bir tanımı bulunmamaktadır (Starovoytova ve Namango, 2016). Ancak kopya çekmeye yönelik tanımlar incelendiğinde bunların; bireyin daha önceden hazırladığı notlardan sınav esnasında gizlice yararlanmasına, sınava giren diğer kişilere gizlice yardım etmesine veya onlardan yardım almasına ve kendisine haksız biçimde avantaj sağlamasına yönelik olgular bağlamında tanımlandığı görülmektedir (Kaymakcan, 2002; O'Rourke ve ark., 2010; Özyurt ve Eren, 2014; Topçu ve Uzundumlu, 2011). Dolayısıyla, bu çalışmada kopya çekme, öğrencilerin kendilerine ve/veya başkalarına haksız biçimde avantaj sağlamak amacıyla sınav vb. değerlendirme süreçleri esnasında, ölçme ve değerlendirme sonuçlarının 
nesnelliğini olumsuz yönde etkileyecek çeşitli yöntemler (yanındaki arkadaşıyla sınav kâğıdını değiştirme vb.) kullanmaları ve/veya araçlardan (cep telefonu vb.) yararlanmaları olarak tanımlanmıştır.

Kopya çekmenin çeşitli nedenleri bulunmaktadır. Anderman ve Murdock (2007) bunları bireysel ve sosyal nedenler olarak sınıflandırmış ve başar1lı olma konusunda ailenin bask1 yapması gibi olguları bireysel nedenlere, akranlar arasında kopyanın kabul edilebilir bir davranış olarak algılanması gibi olguları ise sosyal nedenlere örnek olarak vermiştir. Polat (2017) ise, kopya çekmenin nedenlerini üç ayrı boyut aracılığıyla özetlemiştir. Bunlar; kişisel (cinsiyet, eğitim durumu vb. nedenler), durumsal (ortamın özellikleri, akran baskısı vb. nedenler) ve politika (sınav kuralları ve yaptırımlarıly ilgili nedenler) boyutlarıdır.

Polat'ın (2017) kişisel boyutta yer aldığını ifade ettiği cinsiyet ve eğitim düzeyi gibi demografik değişkenlere ek olarak, psikolojik değişkenlerin de (örneğin öz-yeterlik inanc1, kontrol odağı vb.) kişisel boyutta yer aldığı söylenebilir. Bu boyutta yer alan bir diğer değişken de kopya çekmeye yönelik tutum değişkenidir. Tutum, genel anlamda, herhangi bir nesne, olgu ya da olaya yönelik davranışta bulunma/benimseme eğilimi ve/veya bu bağlamda gerçekleşen psikolojik bir hazırlık durumu olarak tanımlanabilir (Maio ve Haddock, 2010). Buna göre kopya çekmeye yönelik tutum, kopya çekme kavramına ilişkin olarak yukarıda yapılan tanımla tutarlı olarak, öğrencilerin kopya çekmeye yönelme eğilimleri ve/veya kopya çekme davranışlarını kabul edilebilir davranışlar olarak algılama/hoş görme eğilimleri olarak tanımlanabilir (Özyurt ve Eren, 2014). Bu tanım, kopya çekmeye yönelmenin ve/veya bunu olumlu bir davranış biçimi olarak algılamanın, psikolojik içeriğe sahip bireysel bir farkl11ık değişkeni olduğu gerçeğiyle de uyumludur (Anderman ve Murdock, 2007). Bu noktada, tutumun yalnızca duyuşsal unsurları (tutum nesnesinden hoşlanma/hoşlanmama vb.) içermediği, bunun yanında bilişsel (tutum nesnesine ilişkin davranışların yanlış/doğru olduğunu düşünme vb.) ve davranışsal (tutum nesnesine yönelik davranışlar sergileme/sergilememe vb.) unsurları da içerdiğinin vurgulanması önemlidir.

Kopya çekmeye yönelik tutum söz konusu olduğunda, tutumun içeriğini oluşturan unsurların ahlaki ve sosyal yönleri/çevreyle ilgili şartları da içerecek şekilde genişlediği ifade edilebilir. Nitekim Ay ve Çakmak (2015) üniversite öğrencilerini kapsayan bir örneklemden hareketle gerçekleştirildikleri çalışmalarında, kopya çekmeye yönelik tutumu 'ahlaki tutum', 'çevresel 
şartlar' ve 'fırsat/beceri' olarak adlandırdıkları üç faktörlü bir yapı aracılı̆̆ıyla tanımlamışlardır. Bu faktörlerin, gerek kopya çekmeye yönelik tutumun ahlaki ve sosyal yönleri içerdiği gerçeğiyle (Anderman ve Murdock, 2007; Polat, 2017), gerekse kendine ve/veya başkalarına haksız biçimde avantaj sağlamanın kopya çekmenin temel amaçlarından biri olduğu gerçeğiyle (O’Rourke ve ark., 2010) tutarlı oldukları söylenebilir. Dolayısıyla, bu araştırmada üniversite öğrencilerinin kopya çekmeye yönelik tutumları, Ay ve Çakmak (2015) tarafından geliştirilen üç faktörlü yapı aracılığıyla incelenmiştir.

\section{Akademik Alan Memnuniyeti}

Akademik alan seçiminden duyulan memnuniyet, daha çok bilişsel bir değişken olarak incelenmekte (Diener, Emmons, Larsen ve Griffin, 1985) ve hayattan duyulan memnuniyet (Shin ve Johnson, 1978) kavramına paralel biçimde tanımlanmaktadır. Buna göre, akademik alan seçiminden duyulan memnuniyetin, öğrenim görülen alana yönelik seçimle ilgili değerlendirmeyi ifade ettiği söylenebilir. Söz konusu değerlendirme süreci bilişsel bir içeriğe sahipken, bu seçim nedeniyle öğrencinin hissettikleri duyuşsal bir içeriğe sahiptir. Üstelik söz konusu değerlendirme sürecinin tümüyle bilişsel bir içeriğge sahip olduğunu öne sürmek, alan seçimine ilişkin değerlendirmenin tümüyle mantıksal içeriğe sahip bir sorgulama ve bu doğrultuda bir çıkarımda bulunma süreci olduğunu ve örneğin, bu seçimden dolayı hissedilen mutluluğun/hayal kırıklığının söz konusu sürece ve bu doğrultuda yapılan çıkarıma/çıkarımlara hiçbir şekilde eşlik etmediğini öne sürmekle aynı anlama gelmektedir. Oysa görece yakın geçmişte gerçekleştirilen araştırmalar, bilişsel süreçlerin duyuşsal süreçlerle güçlü biçimde ilişkilendiğini göstermektedir (Pessoa, 2008; Phelps, 2006). Nitekim Nauta (2007) üniversite öğrencilerinden hareketle gerçekleştirdiği iki ayrı çalışma aracılığıyla öğrencilerin alan seçiminden duydukları memnuniyetin hem bilişsel (bir başka alana geçmeyi düşünme vb.) hem de duyuşsal (alan seçiminden dolayı mutlu olma vb.) içeriğe sahip maddelerden oluşan tek faktörlü bir yapı aracılığıyla tanımlanabildiğini göstermiştir. Ölçme aracı, hem Erdoğan ve Arsal (2015) hem de Akın, Odabaşı ve Özçelik (2015) tarafından gerçekleştirilen çalışmalar aracılığıyla Türkçeye uyarlanmıştır.

Erdoğan ve Arsal (2015), 354 üniversite öğrencisinin oluşturduğu bir örneklemden hareketle, Nauta (2007) tarafindan geliştirilen Akademik Alan Memnuniyeti Ölçeği'nin yapı geçerliğini ve iç tutarlılık ile test-tekrar test güvenirliklerini incelemişler ve ölçme aracının tek faktörlü yapısının 
araştırmanın verileriyle iyi bir uyum gösterdiğini, yüksek iç tutarlılık ve testtekrar test güvenirliğine sahip olduğunu saptamışlardır. Benzer yönde bulgular Akın ve arkadaşları (2015) tarafından gerçekleştirilen uyarlama çalışmasında da elde edilmiştir. Dolayısıyla, bu araştırmada üniversite öğrencilerinin akademik alan seçiminden duydukları memnuniyet, Nauta (2007) tarafından geliştirilen modele (tek faktörlü ve altı maddeden oluşan model) dayalı olarak incelenmiştir. Ancak bu araştırmada, ölçme aracının bundan önce gerçekleştirilen çalışmalarda elde edilen Türkçe çevirileri kullanılmamıştır. Bunun nedeni, söz konusu çalışmadan farklı olarak, bu çalışmada ölçme aracını oluşturan maddelerin komite yaklaşımına göre Türkçeye uyarlanmasının hedeflenmiş olmasıdır. Nitekim komite yaklaşımı, geri-çeviri (back-translation) vb. çeviri yaklaşımlarına kıyasla orijinal içerikteki kültürel yanlılığı azaltmaya ve anlam odaklı bir uyarlama yapmaya daha fazla imkân veren bir yaklaşımdır (Douglas ve Craig, 2007; Furukawa, Driessnack ve Colclough, 2014).

Konuyla ilgili alanyazın incelendiğinde, akademik alan seçiminden duyulan memnuniyetin okulu bırakmayla olumsuz yönde ve akademik başarıyla olumlu yönde ilişkilendiği (McIlveen, Beccaria ve Burton, 2013; Wiers-Jenssen, Stensaker ve Grøgaard, 2002) görülmektedir. Bunlarla birlikte, öğrencilerin öğrenim gördükleri okulu sevmemelerinin ve/veya kendilerini okulla özdeşleştirmemelerinin kopya çekmeye yönelik tutumlarıyla anlamlı düzeyde ve seçici biçimde ilişkilendiğini gösteren çalışmalar da bulunmaktadır (Bozdoğan ve Öztürk, 2008; Calabrese ve Cochran, 1990; Lüle-Mert, 2012). Bu araştırmalarda öğrencilerin akademik alan seçiminden duydukları memnuniyet dikkate alınmamasına karşın, okulu sevmemenin ve/veya kendini okula ait hissetmemenin kopya çekmeye yönelik tutumla anlamlı düzeyde ve pozitif yönde ilişkilenmesi, söz konusu değişkenler arasındaki olası bir ilişkinin rastlantı olma olasıllğının düşük olduğu anlamına gelmektedir. Nitekim akademik alan seçiminden duyulan memnuniyetle kopya çekmeye yönelik tutum arasındaki ilişkinin incelendiği az sayıda araştırma aracılığıyla elde edilen bulgular, öğrencilerin akademik alan seçiminden duydukları memnuniyetin (ya da başka bir bölümde okumayı tercih etmeme durumlarının) kopya çekmeye yönelik tutumlarıyla anlamlı düzeyde ve negatif yönde ilişkilendiğini göstermiştir (Munoz-Garcia ve Herrera, 2014; Soytürk ve ark., 2015). Diğer taraftan, alanyazında bunun aksini gösteren araştırmalar da bulunmaktadır. Örneğin Çetin (2007), öğrenim gördüğü alandan memnun olduğunu belirten öğrencilerin kopya çekmeye yönelik tutumlarının görece daha olumlu olduğunu saptamıştır. Daha önce değinildiği gibi, bu çelişki, akademik alan seçiminden 
duyulan memnuniyetin kopya çekmeye yönelik tutumla olan ilişkisinde aracı rolü oynama potansiyeli içeren değişkenlerin (örneğin, akademik kontrol odağı) dikkate alınmamasından kaynaklanmış olabilir. Dolayısıyla, bu araştırmada akademik kontrol odağının söz konusu ilişkideki olası aracı rolü de sorgulanmıştır.

\section{Akademik Öz-Yeterlik İnancı}

Öğrencilerin kopya çekmeye yönelik tutumlarıyla ilişkilenme potansiyeli içeren bir diğer önemli değişken, akademik öz-yeterlik inançlardır. Özyeterlik inanc1 "belirli bir amaca ulaşmak için gerekli eylemleri düzenleme ve uygulama konusunda bireyin kendi kapasitesine duyduğu inanç" (Bandura, 1997, s.3) olarak tanımlanabilir. Bireylerin öz-yeterlik inançları, belirli bir öğrenme alanına (matematik, psikoloji vb.), bu alanla ilgili belirli konulara (geometri, kişilik vb.) ve/veya belirli bir kavramın genel görünümüne yönelik olabilir. Bu nedenle, bir araştırmada öz-yeterlik inançlarının odağı belirlenirken, araştırmaya dâhil edilen diğer değişkenlerin genel ya da spesifik olma özelliklerinin dikkate alınmasının gerekli olduğu söylenebilir. Örneğin, öğrencilerin matematik ders başarısının matematik dersine ilişkin öz-yeterlik inançlarıyla birlikte incelenmesi, genel öz-yeterlik inançlarıyla birlikte incelenmesine göre, araştırmada odaklanılan problem durumunun çözümüne yönelik katkıların belirgin olması açısından çok daha mantıklı bir yaklaşım olabilir. Dolayısıyla, bu araştırmada, öğrencilerin genel öz-yeterlik inançları değil, akademik öz-yeterlik inançları dikkate alınmıştır. Akademik öz-yeterlik inanc1, bir öğrencinin akademik olarak başarılı olmasını sağlayacak potansiyele/yeterliğe sahip olduğuna ilişkin inancı olarak tanımlanabilir (Schunk, 1991; Wood ve Locke, 1987; Zajacova, Lynch ve Espenshade, 2005).

Türkiye dışında gerçekleştirilen araştırmalarda, öğrencilerin akademik öz-yeterlik inançlarıyla genelde akademik usulsüzlüğe yönelme eğilimleri, özelde ise kopya çekmeye yönelik tutumları arasında anlamlı düzeyde ve negatif yönde ilişki bulunduğu rapor edilmiştir (Elias, 2009; Marsden, Carroll ve Neill, 2005; Murdock, Hale ve Weber, 2001; Umaru, 2013; Yan-Nora ve Chen-Zang, 2010). Benzer bulgular, Türkiye'de gerçekleştirilen az sayıda araştırma aracılığıyla da elde edilmiştir. Bu araştırmaların bulguları, akademik öz-yeterlik inançlarıyla etik olmayan davranışlar arasında zayıf ve negatif yönde bir ilişki bulunduğunu (Akyüz, Kesen ve Oğrak, 2016) ve başarısızlık korkusu ile yardıma ihtiyaç duymanın, öğrenciler tarafından kopya çekmenin temel nedenleri olarak algılandığını göstermiştir (Özden ve ark., 2015). 
Benzer biçimde, öğretmen adaylarıyla gerçekleştirilen çalışmalar da güvensizlik, kopya çekmeksizin başarılı olamayacağı duygusu (Yangın ve Kahyaoğlu, 2009) ve not/sınav kaygısının (Bozdoğan ve Öztürk, 2008; Er ve Gürgan, 2011; Eraslan, 2011; Seven ve Engin, 2008) öğretmen adayları tarafindan kopya çekmeyi etkileyen önemli faktörler olarak algılandığını ortaya koymuştur.

Yukarıda yapılan açıklamalar ve özetlenen araştırmalar, akademik özyeterlik inançlarının, kopya çekmeye yönelik tutumla ve kopya çekmeyle ilgili değişkenlerle (akademik usulsüzlüğe yönelme eğilimi vb.) anlamlı düzeyde ve seçici biçimde ilişkilendiğine; dolayısıyla, kopya çekmeye yönelik tutumla akademik öz-yeterlik inançları arasındaki ilişkinin dikkate alınmasının mantıklı olduğuna işaret etmektedir. Bu nedenle, bu araştırmada, kopya çekmeye yönelik tutum ve alan seçiminden duyulan memnuniyet değişkenleriyle birlikte, öğrencilerin akademik öz-yeterlik inançları da dikkate alınmıştır. Konuyla ilgili alanyazında (Jerusalem ve Schwarzer, 1981; Yeşilyurt, 2014), akademik öz-yeterlik inançları, belirli bir kavramın genel görünümüyle ilgili olması nedeniyle genellikle tek faktörlü modeller ve bu doğrultuda geliştirilen ölçme araçlarıyla incelendiği görülmektedir. Bu araştırmada da benzer bir yaklaşım benimsenmiş ve öğrencilerin akademik öz-yeterlik inançlarının incelenmesinde Jerusalem ve Schwarzer (1981) tarafından geliştirilen, Yılmaz, Gürçay ve Ekici (2007) tarafından Türkçeye uyarlanan tek faktörlü ölçme aracı kullanılmıştır.

\section{Akademik Kontrol Odağı}

Kontrol odağı, bireylerin olumlu veya olumsuz yaşantılarını değerlendirirken başvurdukları nedensel inançlar olarak tanımlanabilir (Rotter, 1966). Rotter (1966), kontrol odağının içsel kontrol odağı ve dışsal kontrol odağı olmak üzere iki ana eksende değerlendirilebildiğini belirtmiştir. İçsel kontrol odağına sahip bireyler, hayat deneyimlerini kendi edimlerinin bir sonucu olarak değerlendirme eğilimindeyken; dışsal kontrol odağına sahip bireyler hayat deneyimlerini kendi edimleri dışındaki olgulara ve süreçlere bağlama eğilimindedirler (Rotter, 1966, 1990). Örneğin, içsel kontrol odağına sahip bireyler elde ettikleri yüksek ya da düşük başarıyı, gösterdikleri çabanın bir fonksiyonu olarak açıklama, başarı için kişisel anlamda sorumluluk alma eğilimindeyken, dışsal kontrol odağına sahip bireyler başarı ya da başarısızlığı şans, kader, fiziksel/sosyal koşullar gibi dışsal gerekçelerle açıklama ve başarı için kişisel anlamda çok daha az sorumluluk alma eğilimindedirler. Kontrol odağ 1 
kavramı, öz-yeterlik inancına benzer biçimde, bireylerin kontrol odağını hangi hayat deneyimi/deneyimleri (akademik performans, evlilik, ticari girişimler vb.) bağlamında değerlendirdiklerine göre incelenebilir. Akademik kontrol odağı, bireylerin okul gibi akademik ortamlardaki performanslarını içsel ya da dışsal nedenlere dayalı olarak açıklamalarıyla ilgili bir kavram olarak dikkate alındığında (Hans, 2000; İskender ve Akın, 2010), bu ortamlarda elde edilen akademik sonuçların içsel (çaba vb.) veya dışsal (şans vb.) faktörlere atıfla açıklanması olarak tanımlanabilir (Daum ve Wiebe, 2003).

$\mathrm{Bu}$ açıklamalar 1şığında, öğrencilerin akademik kontrol odaklarının içsel ya da dışsal olmasının, eğitim ortamları gibi başarı odağının belirgin olduğu akademik ortamlarda önemli sonuçları olacağı ifade edilebilir. Dolay1sıyla, bu araştırmada akademik kontrol odağı, yukarıda değinilen kavramsal çerçeveye uygun biçimde (Rotter, 1966), içsel akademik kontrol odağ 1 ve dişsal akademik kontrol odağı olarak adlandırılan iki faktörlü bir yapı aracılığıyla incelenmiştir. Bu bağlamda gerçekleştirilen araştırmalar, içsel akademik kontrol odağına sahip öğrencilerin, dışsal akademik kontrol odağına sahip akranlarına göre anlamlı düzeyde daha yüksek akademik başarıya sahip olduğunu göstermiştir (Nunn ve Nunn, 1993; Uguak, Habibah, Jegak ve Turiman, 2007; Wood, Saylor ve Cohen, 2009).

Bununla birlikte, kontrol odağı ve kopya çekme davranış1/akademik usulsüzlük/kopya çekmeye yönelik tutum eğilimi arasındaki ilişkilerin incelendiği araştırmalardan elde edilen bulgular, dışsal akademik kontrol odağının kopya çekme davranışını anlamlı düzeyde ve pozitif yönde yordadığını (Coleman ve Mahaffey, 2000; Gallagher, 2010; Pino ve Smith, 2003); akademik usulsüzlük eğilimi/kopya çekmeye yönelik tutum ve dışsal akademik kontrol odağı arasında anlamlı düzeyde ve pozitif yönde, söz konusu değişkenlerle içsel akademik kontrol odağı arasında ise zayıf düzeyde ve negatif yönde bir ilişki bulunduğunu da göstermiştir (Büyükgöze, 2017; Certel, Bahadır, Saracaloğlu ve Varol, 2017; Rinn ve Boazman, 2014). Ayrıca, Yeşilyurt (2014) 256 öğretmen adayını kapsayan araştırmasında, akademik kontrol odağı, akademik usulsüzlük eğilimi, sınav kaygısı ve akademik öz-yeterlik inançları arasındaki ilişkileri incelemiştir. Akademik usulsüzlük eğilimi ve sınav kaygısının kontrol odağını orta düzeyde ve pozitif yönde yordadığını, akademik kontrol odağının da sırasıyla akademik öz-yeterlik inançlarını oldukça güçlü düzeyde ve yine pozitif yönde yordadığını saptamıştır. Ancak Yeşilyurt'un (2014) araştırmasında, akademik kontrol odağının ikinci sıra faktör yapısıyla 
tanımlanması ve bu değişkenin diğer değişkenlerle olan ilişkilerinin bu faktör yapısına dayalı olarak incelenmesi nedeniyle, dışsal ya da içsel akademik kontrol odağının söz konusu değişkenlerle nasıl ilişkilendiğine yönelik bir çıkarımda bulunmak mümkün değildir. Üstelik Yeşilyurt'un (2014) araştırmasında, sınav kaygısı, akademik usulsüzlük eğilimi ve akademik öz-yeterlik inançları arasındaki ilişkilerde, akademik kontrol odağının aracı rolüne odaklanılmamış ve sınav kaygısıyla akademik usulsüzlük eğiliminin akademik özyeterlik inançları üzerindeki doğrudan etkileri de incelenmemiştir (Yeşilyurt, 2014, bkz. Şekil 5). Dolayısıyla, Yeşilyurt'un (2014) araştırmasından hareketle, akademik kontrol odağının söz konusu değişkenler arasındaki ilişkilerde aracı rolü oynayıp oynamadığına ilişkin bir çıkarımda bulunmak da mümkün görünmemektedir. Bu sınırlılıklarına rağmen, Yeşilyurt'un (2014) araştırmasında elde edilen bulguların, akademik kontrol odağının, akademik öz-yeterlik inançları ve kopya çekmeye yönelik tutum değişkenleri arasındaki ilişkide aracı rolü oynama potansiyeline işaret ettiği söylenebilir. Bu nedenle, bu araştırmada akademik kontrol odağının aracı rolüne de odaklanılmıştır.

\section{Yöntem}

\section{Araştırma Modeli}

$\mathrm{Bu}$ araştırmada tarama (survey) yöntemi kullanılmıştır. Araştırmanın deseni ise açımlayıcı ilişkisel desendir (exploratory correlational design). Söz konusu desen, araştırma değişkenleri arasındaki ilişkilere yönelik az sayıda kanıt bulunduğunda ya da hiç kanıt bulunmadığında sıklıkla kullanılan ve değişkenler arasındaki ilişkilerin tümevarıma dayalı bir bakış açısıyla incelenmesine olanak sağlayan bir desendir (Fraenkel, Wallen ve Hyun, 2012).

\section{Çalışma Grubu}

Araştırmanın örneklemini, Türkiye'nin Batı Karadeniz bölgesindeki büyük bir üniversitenin (yaklaşı 31.000 öğrenci) eğitim, mühendislik, fenedebiyat ve ilahiyat fakültelerinin çeşitli bölümlerinde öğrenim gören öğrenciler arasından, kolayda örnekleme (convenient sampling) yöntemine ve gönüllü katılım esasına dayalı olarak seçilen toplam 715 öğrenci $(\mathrm{K} ı=452$; Erkek=263) oluşturmuştur. Ayrıntılı olarak, örneklemi oluşturan öğrenciler söz konusu fakültelerin; psikoloji $(\mathrm{n}=103)$, sosyoloji $(\mathrm{n}=175)$, bilgisayar mühendisliği $(n=84)$, makine mühendisliği $(n=116)$, ilahiyat $(n=91)$, matematik öğ retmenliği $(n=63)$ ve fen bilgisi öğretmenliği $(n=83)$ bölümlerinin; birinci (n=209), ikinci, ( $n=264)$, üçüncü ( $n=153)$ ve dördüncü $(n=89)$ sinıflarında öğrenim görmektedirler. Öğrencilerin yaş ortalaması 20.50 ( $\mathrm{SS}=2.01)$ olarak 
hesaplanmıştır.

\section{Veri Toplama Araçları}

Araştırmada kullanılan ölçme araçlarının, bu araştırmanın örneklemi kapsamında yapı geçerliliklerinin sınanması amacıyla, en yüksek olabilirlik tahmini yöntemi (Maximum Likelihood Method of Estimation-ML) kullan1larak bir dizi doğrulayıcı faktör analizi (DFA) gerçekleştirilmiştir. Ölçme araçlarını oluşturan faktör yapılarının, bu araştırmanın verileriyle kabul edilebilir bir uyum gösterip göstermediklerinin değerlendirilmesinde Karşılaştırmalı Uyum İndeksi (Comparative Fit Index; CFI $\geq .90$ ), Tucker-Lewis İndeksi (Tucker-Lewis Index; TLI $\geq .90$ ), Yaklaşık Hataların Ortalama Karekökü (Root Mean Square Error of Approximation; RMSEA $\leq .08$ ) ve Standartlaşt1rılmış Artık Ortalamaların Karekökü (Standardized Root Mean Square Residual; SRMR $\leq .08$ ) kullanılmıştır (Kline, 2011). Ayrıca her bir veri toplama aracının çarpıklık ve basıklık değerlerinin \pm 1.00 aralığında olduğu ve \%1 güven aralığ olan \pm 1.96 istatistiki değerler (Field, 2009) içinde yer alarak normal dağılım gösterdiği tespit edilmiştir. Araştırmada kullanılan ölçme araçlarının özellikleri aşağıda sırasıyla özetlenmiştir.

\section{Kopya Çekmeye Yönelik Tutum Ölçeği}

Öğrencilerin kopya çekmeye yönelik tutumlarının incelenmesi amacıyla, Ay ve Çakmak (2015) tarafından geliştirilen Kopya Çekmeye Yönelik Tutum Ölçeği kullanılmıştır. Ölçme aracı 'ahlaki tutum' (Toplam 7 madde: Örneğin, “Kopya çekmek başkasının hakkını yemektir.”), 'çevresel şartlar' (Toplam 4 madde: Örneğin "Hemen herkes kopya çektiğine göre, kopya çekmek kötü bir davranış olarak düşünülemez.") ve 'firsat/beceri' (Toplam 5 madde: Örneğin, "Yakalanılmadığı sürece kopya çekmenin sakıncalı bir tarafı yoktur.") olarak adlandırılan üç faktörden ve toplam 16 maddeden oluşmaktadır. Öğrenciler, ölçme aracında yer alan maddelere ilişkin görüşlerini, 1 (kesinlikle katılmıyorum) ve 5 (kesinlikle katılıyorum) arasında değişen yanıt seçeneklerini dikkate alarak belirtmişlerdir.

DFA sonucunda, kopya çekmeye yönelik tutum ölçeğinin üç faktörlü yapısının, bu araştırmanın örneklemi kapsamında elde edilen verilerle iyi bir uyum gösterdiği saptanmıştır $\quad\left(\chi^{2}(100)=388.61 ; \quad\right.$ CFI=.953; TLI=.944; RMSEA=.064; SRMR=.038). Bununla birlikte, ölçme aracını oluşturan faktörlerin, .70 ile .90 arasında değişen gizil korelasyon katsayılarıyla, birbirleriyle güçlü biçimde ilişkilendikleri saptanmıştır. Dolayısıyla, ölçme aracını oluşturan faktörlerin, genel bir faktörün (kopya çekmeye yönelik tutum) 
göstergeleri olarak açıklanıp açıklanmadıklarının sorgulanması amacıyla, ikinci sıra faktör (gizil bir değişken tarafindan açıklanan üç faktörlü yapı) analizi de gerçekleştirilmiş ve elde edilen sonuçlar birinci sıra faktör analizi (üç faktörlü yap1) aracılığıyla elde edilen sonuçlarla karşılaştırılmıştır. Söz konusu karşılaştırmada, birinci ve ikinci sıra faktör yapıları için hesaplanan Akaike Enformasyon Ölçütü (Akaike Information Criterion-AIC) değerleri arasındaki fark dikkate alınmıştır ( $\triangle \mathrm{AIC}<10$; Burnham ve Anderson, 2002). Sonuç olarak, ikinci sıra faktör yapısı için hesaplanan AIC değeriyle (460.61), birinci sıra faktör yapısı için hesaplanan AIC değerinin (460.61) aynı olduğu saptanmıştır $(\triangle \mathrm{AIC}=0)$. Buna göre, bu araştırmada, ölçme aracının hem ikinci sıra hem de birinci sıra faktör yapısının kullanılmasının mümkün olduğu söylenebilir. Ancak ölçme aracının faktörleri arasındaki güçlü ilişkilerin, araştırma sorularının yanıtlanmasına ilişkin analizlerde çoklu eş-doğrusallık (multicollinearity) problemine yol açma ihtimaliyle, bu araştırmada kopya çekmeye yönelik tutum ölçeğinin ikinci sıra faktör yapısı kullanılmıştır. Nitekim ölçme aracının ahlaki tutum (.89), çevresel şartlar (.78), firsat ve beceri (.87) faktörleri için hesaplanan Cronbach Alfa $(\alpha)$ katsayılarına benzer biçimde, ikinci sıra faktör yapısı için hesaplanan alfa katsayısının da (.93) oldukça yüksek olduğu gözlenmiştir (DeVellis, 2017).

\section{Akademik Alan Memnuniyeti Ölçeği}

Öğrencilerin alan seçiminden duydukları memnuniyet, Nauta (2007) tarafından geliştirilen ve bu araştırma kapsamında Türkçeye uyarlanan, Akademik Alan Memnuniyeti Ölçeği aracıllğıyla elde edilen verilerden hareketle değerlendirilmiştir. Ölçme aracının maddeleri komite yaklaşımı kapsamında (bkz. Douglas ve Craig, 2007), öncelikle araştırmacılar tarafindan Türkçeye çevrilmiş; daha sonra ise maddelerin çevirileri yabancı dil öğretimi alanından iki uzmanın yardımıyla incelenmiştir. Üzerinde uzlaşılmayan çevirilere ilişkin olarak kapsamlı bir tartışma süreci gerçekleştirilmiş ve bu doğrultuda söz konusu çeviriler yeniden incelenmiştir. Maddelerin Türkçe çevirileri yabancı diller alanından başka bir uzmanın da görüşüne sunularak, anlam odaklı bir bakış açısıyla ayrıca değerlendirilmiştir. Son olarak, maddelerin Türkçe çevirileri Türk dili alanından bir uzmanın görüşüne sunularak, Türkçe anlamları açısından da incelenmiştir. Bu merhaleden sonra, ölçme aracını oluşturan maddelerin Türkçe çevirilerine son şekli verilmiştir.

Ölçme aracı, tek faktörden ve toplam altı maddeden oluşmaktadır (örnek madde: “Genel olarak seçtiğim alandan memnunum.”). Ölçme aracında 
dört olumsuz madde bulunmaktadır (örnek madde: "Bu alanı seçmemiş olmayı isterdim.”). Öğrenciler, ölçme aracındaki maddelere ilişkin görüşlerini, 1 (kesinlikle katılmıyorum) ve 5 (kesinlikle katılıyorum) arasında değişen seçenekleri dikkate alarak ifade etmişlerdir. DFA sonucunda, ölçme aracının tek faktörlü yapısının bu araştırmanın örneklemi kapsamında elde edilen verilerle oldukça iyi bir uyum gösterdiği saptanmıştır $\left(\chi^{2}(7)=20.50\right.$; CFI=.996; TLI=.992; RMSEA=.052; SRMR=.019). Maddeler bu araştırmada Türkçeye uyarlandığı için, ölçme aracının faktör yapısı Sıralı (Ordinal) Faktör Analizi (SFA) gerçekleştirilerek ayrıca sorgulanmıştır (Ferrando ve Lorenzo-Seva, 2017). Söz konusu analiz, çok değişkenli normallik varsayımı ile likert tipi yanıt formatındaki seçeneklerin özünde sıralı değişken olma özelliğinin kontrol edilmesi amacıyla kovaryans matrisi bağlamında ve ML yöntemi kullanılarak değil, polikorik korelasyon matrisi bağlamında ve ağırlıklandırılmamış sağlam en küçük kareler yöntemi (Robust Unweighted Least Squares Method) kullanılarak gerçekleştirilmiştir (Ferrando ve Lorenzo-Seva, 2018).

Sonuçlar; (a) polikorik korelasyon matrisinin yeterli olduğunu (KaiserMeyer-Olkin=.83; Bartlett (15)=6721.30, $p<.001$ ); (b) ölçme aracının tek faktörlü yapı aracılığıyla oldukça iyi açıklandığını (Tek Boyutlu UyumUniCo=.997); (c) tek faktörlü yapının toplam varyansın \%82'sini açıkladığını (Eigen değeri=4.90); (d) maddelerin faktörle güçlü biçimde ilişkilendiğini (en düşük=.74; en yüksek=.92); (e) tek faktörlü yapının, gözlemlenen madde puanlarının temelini oluşturan ve öğrencilerin görüsslerini ifade etmek için kullandıkları yanıt seçenekleri kapsamında güvenilir biçimde tanımlandığını (Hancock's $H=.97$ ); (f) tek faktörlü ve altı maddeli yapının, bu araştırmanın verileriyle oldukça iyi bir uyum sergilediğini göstermiştir $\left(\chi^{2}(9)=31.08\right.$; $\mathrm{CFI}=.989$; TLI=.982; RMSR=.054; WRMR=.105). Önemli olarak, bu analizlerde, yanlı sonuçlar verebildiği ve iyi uyum gösteren modellerde bile görece yüksek değerler alabildiği için (Shi, Maydeu-Olivares ve Rosseel, 2020), RMSEA değeri yerine ağırlıklandırılmış artık değerlerin ortalama karekökü (WRMR) rapor edilmiş ve bu değerin iyi bir uyuma işaret ettiği görülmüştür (WRMR <1.00; DiStefano, Liu, Jiang ve Shi, 2017). Ayrica Kelley'in (1935) ölçütüne (.037) yakın bir değere sahip olmasıyla, SFA kapsamında hesaplanan artık değerlerin ortalama karekökünün de (RMSR) iyi bir uyuma işaret ettiği belirtilebilir. Ölçme aracının iç tutarlılık güvenirliğine ilişkin alfa katsayısı ise .92 olarak hesaplanmış ve yüksek bulunmuştur. Yukarıda özetlenen sonuçların, önceki araştırmalarda elde edilen sonuçlarla tutarlı olduğu söylenebilir (Akın ve ark., 2015; Erdoğan ve Arsal, 2015). 


\section{Akademik Öz-Yeterlik Ölçeği}

Öğrencilerin akademik öz-yeterlik inançları, Jerusalem ve Schwarzer (1981) tarafından geliştirilen ve Y1lmaz, Gürçay ve Ekici (2007) tarafından Türkçeye uyarlanan Akademik Öz-Yeterlik Ölçeği aracılığıyla elde edilen verilere dayalı olarak ölçülmüştür. Ölçme aracı tek faktörden ve toplam 7 maddeden oluşmaktadır (örnek madde: "Başarısız olacağım herhangi bir sınav düşünemiyorum.”). Öğrenciler, ölçme aracındaki maddelere ilişkin görüşlerini, 1 (bana hiç uymuyor) ve 4 (bana tamamen uyuyor) arasında değişen seçenekleri dikkate alarak belirtmişlerdir. DFA sonucunda, ölçme aracının faktör yapısının bu araştırmada elde edilen verilerle iyi bir uyum gösterdiği saptanmış$\operatorname{tır}\left(\chi^{2}(13)=52.84 ; \mathrm{CFI}=.970 ; \mathrm{TLI}=.951 ; \mathrm{RMSEA}=.066\right.$; SRMR=.031). Ölçme aracının iç tutarlılık güvenirliğine ilişkin alfa katsayısı ise .80 olarak hesaplanmış ve yüksek bulunmuştur.

\section{Akademik Kontrol Odağı Ölçeği}

Öğrencilerin akademik kontrol odağı, Akın (2007) tarafından geliştirilen Akademik Kontrol Odağı Ölçeği aracılığıyla elde edilen verilere dayalı olarak değerlendirilmiştir. Ölçme aracı dişsal akademik kontrol (Toplam 11 madde: Örneğin, "Derslerde başarılı olabilmek için şans çok önemlidir.") ve içsel akademik kontrol odağı (Toplam 6 madde: Örneğin, "Sınavdan yüksek not alabilmem için o derse iyi çalışmam gerektiğini düşünürüm.”) olarak adlandırılan iki faktörlü yapıdan ve toplam 17 maddeden oluşmaktadır. Öğrenciler, ölçme aracındaki maddelere ilişkin görüşlerini 1 (hiç uygun değil) ve 5 (tamamen uygun) arasında değişen seçenekleri dikkate alarak belirtmişlerdir. DFA sonucunda, ölçme aracının iki faktörlü yapısının bu araştırmanın verileriyle iyi bir uyum sergilediği saptanmıştır $\left(\chi^{2}(111)=226.43\right.$; CFI=.949; TLI=.938; RMSEA=.038; SRMR=.043). Dışsal akademik kontrol odağ1 ve içsel akademik kontrol odağına yönelik alfa katsayıları sırasıyla .72 ve .75 olarak hesaplanmış ve yeterli bulunmuştur (DeVellis, 2017).

\section{Veri Toplanması ve Analizi}

Ölçme araçları, öğrencilerin öğrenim gördükleri bölümlerin öğretim programlarında yer alan dersler esnasında, öğretim elemanlarının uygun gördükleri bir zaman diliminde, birinci yazar tarafindan ve gönüllü katılım esasına göre uygulanmıştır. Araştırmanın amacı araştırmacı tarafından öğrencilere yüksek sesle okunmuş, araştırmaya katılımın gönüllülük esasına dayalı olduğu ve araştırmada elde edilen verilerin gizlilik ilkesi doğrultusunda muhafaza edileceği belirtilmiştir. Ölçme araçları gönüllü katılımcılara, 
araştırmanın amacı ve ölçme araçlarında yer alan maddelerin nasıl yanıtlanacağına ilişkin ayrıntılı açıklamaları içeren bir yönergeyle birlikte verilmiştir. Demografik değişkenlere ilişkin veriler katılımcıların Kopya Çekmeye Yönelik Tutum Ölçeği'nin üzerinde yer alan ilgili kutucukları/boşlukları doldurmasıyla elde edilmiştir. Uygulama yaklaşık 20 dakika sürmüştür. Bu araştırma, araştırmanın gerçekleştirildiği üniversitenin ilgili Etik Kurulu tarafından onaylanmıştır.

Araştırma sorularına ilişkin analizler gerçekleştirilmeden önce demografik değişkenlerin (cinsiyet, yaş, öğrenim görülen alan ve sınıf düzeyi) araştırma değişkenleri üzerindeki olası etkileri incelenmiştir. Ayrıntılı olarak cinsiyet, öğrenim görülen alan ve sınıf düzeyi değişkenlerinin bağımsız, yaş değişkeninin ortak (covariate) ve araştırma değişkenlerinin sırasıyla bağımlı değişkenler olarak belirlendiği üç ayrı tek değişkenli kovaryans analizi (ANCOVA) ve bir de çok değişkenli kovaryans analizi (MANCOVA) gerçekleştirilmiştir (Tabachnick ve Fidell, 2013). Demografik değişkenlerin araştırma değişkenleri üzerindeki etkilerinin incelenmesinde, örneklem büyüklüğüne oldukça hassas bir ölçü olması nedeniyle (Ferguson, 2009) $p$ değerleri değil, etki büyüklükleri dikkate alınmıştır. Bu nedenle, kısmi eta-kare katsayıları $\left(\eta^{2}\right)$ hesaplanmış ve .06'dan küçük katsayılar zayıf bir etki büyüklügünün göstergesi olarak yorumlanmıştır (Richardson, 2011). Kovaryans analizi sonuçları, cinsiyet, yaş, öğrenim görülen alan ve sınıf düzeyi değişkenlerinin araştırma değişkenleri üzerindeki etkilerinin .000 ile .033 arasında değişen büyüklükteki $\eta_{\mathrm{p}}^{2}$ değerleriyle zayıf olduğunu göstermiştir. Kovaryans analizi sonuçları ayrıca, demografik değişkenlerin aralarındaki etkileşimlerin araştırma değişkenleri üzerindeki etkilerinin .002 ile .045 arasında değişen büyüklükteki $\eta^{2}$ p değerleriyle zayıf olduğunu da göstermiş̧ir. Dolayısıyla, demografik değişkenler araştırma sorularının yanıtlanmasına ilişkin olarak gerçekleştirilen analizlere dâhil edilmemiş ve araştırmanın odağında yer almamaları nedeniyle de tartışılmamıştır.

Araştırmanın birinci sorusunun yanıtlanması amacıyla gizil, (latent) değişkenler için korelasyon analizi gerçekleştirilmiştir. Bunun nedeni, bu araştırmadaki verilerin öz-bildirime dayalı ölçme araçları aracılığıyla elde edilmiş olmasıdır. Araştırmanın ikinci sorusunun yanıtlanması amacıyla iki ayrı yapısal model oluşturulmuş ve bu modeller yapısal eşitlik modellemesi (YEM) analizi gerçekleştirilerek incelenmiştir (Kline, 2011). Birinci modelde, akademik alan seçiminden duyulan memnuniyet, akademik öz-yeterlik inanc1, 
dışsal akademik kontrol odağı ve içsel akademik kontrol odağı bağımsız değişkenler; kopya çekmeye yönelik tutum ölçeği ise bağımlı değişken olarak belirlenmiştir. İkinci modelde ise, akademik alan seçiminden duyulan memnuniyet ve akademik öz-yeterlik inancı, dışsal akademik kontrol odağı ve içsel akademik kontrol odağının yordayıcıları olarak belirlenmiştir. İkinci modelin oluşturulma nedeni, aracı değişkenler olarak belirlenen dişsal akademik kontrol odağı ile içsel akademik kontrol odağı değişkenlerinin, akademik alan seçiminden duyulan memnuniyet ve akademik öz-yeterlik inancı tarafından anlamlı düzeyde yordanıp yordanmadığının incelenmesidir.

Araştırmanın üçüncü sorusu, ikinci soru kapsamında gerçekleştirilen YEM analizlerinin sonuçlarından hareketle oluşturulan YEM modeli bağlamında yanıtlanmıştır. Bu model, araştırmanın ikinci sorusu kapsamında gerçekleştirilen YEM analizleri sonucunda, birbirleriyle anlamlı düzeyde ilişkilendiği saptanan değişkenler dikkate alınarak oluşturulmuştur. YEM analizleri AMOS 21 programı (Arbuckle, 2012) kullanılarak gerçekleştirilmiştir. Tüm analizler, normal dağılım varsayımının etkili biçimde kontrol edilmesi ve Tip I hata olasılığının azaltılması amacıyla, parametrik olmayan bir yöntem olan yüzdelik yeniden örnekleme yöntemi kullanılarak (percentile bootstrap method), $1000 \mathrm{kez}$ yeniden örnekleme seçeneğiyle ve $\% 95$ güven aralığında gerçekleştirilmiştir (Hayes ve Scharkow, 2013).

\section{Bulgular}

\section{Korelasyon Analiziyle Elde Edilen Bulgular}

Gizil korelasyon analizi sonucunda, araştırma değişkenlerinin birbirleriyle sınırlandırılmaksızın ilişkilendirildiği modelin, araştırmanın verileriyle kabul edilebilir bir uyum sergilediği görülmüsstür $\left(\chi^{2}(960)=1896.09\right.$; $\mathrm{CFI}=.934$; TLI=.928; RMSEA=.037; SRMR=.052). Buna göre, araştırma değişkenlerinin istatistiksel açıdan birbirleriyle örtüşmediği ve aralarındaki ilişkilerin incelenmesinin mantıklı olduğu söylenebilir. Sonuçlar Tablo 1'de özetlenmiştir. 
Tablo 1.Betimsel İstatistikler ve Gizil Korelasyon Analizi Sonuçları

\begin{tabular}{lllllllll}
\hline Değişken & $\bar{X}$ & SS & $\begin{array}{c}\text { Carpıklık/ } \\
\text { Basıklık }\end{array}$ & $\mathbf{1}$ & $\mathbf{2}$ & $\mathbf{3}$ & $\mathbf{4}$ & $\mathbf{5}$ \\
\hline Akademik alan memnuniyeti & 23.95 & 5.71 & $-.72 /-.35$ & - & & & & \\
Akademik öz-yeterlik inancı & 26.98 & .86 & $-.53 /-.38$ & $.23^{* *}$ & - & & & \\
Dışsal akademik kontrol odağı & 25.91 & 6.42 & $.13 /-.23$ & $-.34^{* *}$ & $-.52^{* *}$ & - & & \\
İçsel akademik kontrol odağı & 11.81 & 2.34 & $-.64 / .42$ & $.09^{*}$ & $.26^{* *}$ & $-.23^{* *}$ & - & \\
Kopya çekmeye yönelik tutum & 41.30 & 13.99 & $.19 /-.51$ & $-.18^{* *}$ & $-.21^{* *}$ & $.51^{* *}$ & $-.19^{* *}$ & - \\
\hline${ }^{*} p<.05,{ }^{* *} p<.01$ & & & & & & & &
\end{tabular}

Tablo 1'de görüldügü gibi, akademik alan seçiminden duyulan memnuniyet, akademik öz-yeterlik inanciyla dikkate değer düzeyde ve pozitif yönde; dışsal akademik kontrol odağıyla orta düzeyde ve negatif yönde; içsel akademik kontrol odağıyla oldukça zayıf düzeyde ve pozitif yönde; kopya çekmeye yönelik tutumla da görece zayıf düzeyde ve negatif yönde ilişkilenmiştir. Akademik öz-yeterlik inancı, dışsal akademik kontrol odağıyla güçlü düzeyde ve negatif yönde; içsel akademik kontrol odağıyla dikkate değer düzeyde ve pozitif yönde; kopya çekmeye yönelik tutumla da yine dikkate değer düzeyde, ancak negatif yönde ilişkilenmiştir. Dışsal akademik kontrol odağ ile kopya çekmeye yönelik tutum arasında ise güçlü düzeyde ve pozitif yönde bir ilişki saptanmıştır. Diğer taraftan, içsel akademik kontrol odağı ile kopya çekmeye yönelik tutum arasında negatif yönde ancak zayıf bir ilişki saptanmiştır.

\section{YEM Analiziyle EIde Edilen Bulgular}

Birinci YEM analizi sonucunda, akademik alan seçiminden duyulan memnuniyet, akademik öz-yeterlik inancı, dışsal akademik kontrol odağ 1 ve içsel akademik kontrol odağının, kopya çekmeye yönelik tutumun yordayıcıları olarak belirlendiği modelin (Model 1), araştırmanın verileriyle kabul edilebilir bir uyum sergilediği saptanmıştır $\left(\chi^{2}(960)=1931.16\right.$; CFI=.931; TLI=.926; RMSEA=.038; SRMR=.053). Benzer biçimde, akademik alan seçiminden duyulan memnuniyet ve akademik öz-yeterlik inancının, dışsal akademik kontrol odağı ve içsel akademik kontrol odağının yordayıcıları olarak belirlendiği modelin de (Model 2) araştırmanın verileriyle kabul edilebilir bir uyum sergilediği saptanmıştır $\quad\left(\chi^{2}(389)=908.33 ; \quad\right.$ CFI=.931; TLI=.923; RMSEA=.043; SRMR=.057). Model 1 ve 2'ye ilişkin sonuçlar Tablo 2'de özetlenmiştir. 
Tablo 2. YEM Analizi Sonuçları

\begin{tabular}{lllllll}
\hline & Bağımlı Değişken & Bağımsız Değişken & $\mathbf{B}^{\mathbf{a}}$ & $\mathbf{S H}^{\mathbf{b}}$ & $\boldsymbol{\beta}^{\mathbf{c}}$ & Alt/üst sınır $^{\mathbf{d}}$ \\
\hline \multirow{2}{*}{1 Kopya Çekmeye Yönelik } & Akd. Alan Memnuniyeti & -.05 & .06 & -.04 & $-.14 / .06$ \\
& Tutum & Akd. Öz-Yeterlik İnancı & .05 & .22 & .02 & $-.11 / .16$ \\
& & Dişsal Akd. Kont. Odağı & .92 & .19 & $.50^{* *}$ & $.37 / .64$ \\
& & İçsel Akd. Kont. Odağı & -.22 & .16 & -.08 & $-.19 / .04$ \\
\hline 2 & Dişsal Akd. Kont. Odağı & Akd. Alan Memnuniyeti & -.09 & .02 & $-.25 * *$ & $-.35 /-.11$ \\
& & .01 & .02 & .03 & $-.05 / .11$ \\
& İçsel Akd. Kont. Odağı & & -.46 & .10 & $-.49^{* *}$ & $-.62 /-.29$ \\
& Dişsal Akd. Kont. Odağı & Akd. Öz-Yeterlik İnancı & .31 & .08 & $.26^{* *}$ & $.17 / .36$ \\
\hline
\end{tabular}

** $p<.01$. Not: a. Standartlaştırılmamış Beta katsayısl; $b$. yeniden örnekleme yöntemine dayalı olarak hesaplanan standart hata; c. standartlaştırılmış Beta katsayısı; d. standartlaştırılmış Beta katsayılarının alt (kesiden önceki değer) ve üst (kesiden sonraki değer) sinır değerleri; alt ve üst değerler \%95 güven aralığında hesaplanmıştır.

Tablo 2'de görüldüğü gibi (bkz. Model 1), dışsal akademik kontrol odağı kopya çekmeye yönelik tutumu güçlü düzeyde ve pozitif yönde yordamıştır. Nitekim standartlaştırılmış Beta katsayılarının bu bağlamda hesaplanan alt ve üst sınır değerlerinin her ikisi de pozitif yönde ve güçlü düzeydedir. Ancak diğer değişkenlerin kopya çekmeye yönelik tutumla olan ilişkilerinin anlamlı olmadığ 1 saptanmıştır. Benzer biçimde, söz konusu değişkenlere ilişkin standartlaştırılmış Beta katsayılarının alt ve üst sınır değerleri de tutarlı bir görünüm sergilememiştir. Bunun anlamı, dışsal akademik kontrol odağı dışındaki değişkenlerin, kopya çekmeye yönelik tutum üzerindeki etkilerinin ihmal edilebilir düzeyde olduğudur. Model 1'de yer alan bağımsız değişkenler, kopya çekmeye yönelik tutum değişkenindeki toplam varyansı önemli ölçüde (\%28) ve anlamlı düzeyde $(p<.01)$ açıklamıştır. Bu sonuçlar doğrultusunda, dışsal akademik kontrol odağının kopya çekmeye yönelik tutumun yordayıcısı olarak incelenmesinin mantıklı olduğu belirtilebilir.

Model 2 kapsamında gerçekleştirilen analiz sonuçları, akademik alan seçiminden duyulan memnuniyetin dışsal akademik kontrol odağını anlamlı düzeyde ve negatif yönde yordadığını ancak içsel akademik kontrol odağını anlamlı düzeyde yordamadığını göstermiştir (Tablo 2). Nitekim akademik alan seçiminden duyulan memnuniyetin, dışsal akademik kontrol odağı üzerindeki etkisine yönelik olarak hesaplanan standartlaştırılmış Beta katsayısının alt ve üst değerleri de tutarlı bir görünüme sahiptir. Akademik öz-yeterlik inancının dışsal akademik kontrol odağını anlamlı düzeyde ve negatif yönde, içsel akademik kontrol odağını ise yine anlamlı düzeyde ancak pozitif yönde yordadığı saptanmıştır. Bu bağlamda hesaplanan standartlaştırılmış Beta katsayılarının tutarlı görünümlere sahip olmaları, söz konusu etkilerin önemli 
olduğunu göstermektedir. Model 2'de yer alan bağımsız değişkenler, dışsal akademik kontrol odağı ile içsel akademik kontrol odağındaki toplam varyansın sırasıyla \%35'ini $(p<.01)$ ve \%7'sini $(p<.01)$ açılamıştır. Bu sonuçlardan hareketle, akademik alan seçiminden duyulan memnuniyet ile akademik özyeterlik inancının, içsel akademik kontrol odağından çok, dışsal akademik kontrol odağının yordayıcıları olarak dikkate alınmalarının mantıklı olduğu söylenebilir. Gerek söz konusu bulgulardan hareketle gerekse içsel akademik kontrol odağının aracı rolünün lüzumsuz yere analize dâhil edilmesinin tip 1 hata olasılığını da arttırabileceği sebebiyle yalnızca dışsal akademik kontrol odağının aracılık etkisinin sınanması uygun görülmüştür.

\section{Aracılık Analiziyle Elde Edilen Bulgular}

Araştırmanın ikinci sorusu kapsamında gerçekleştirilen YEM analizi sonuçlarından hareketle, alan seçiminden duyulan memnuniyet ve akademik öz-yeterlik inancının bağımsız, dışsal akademik kontrol odağının aracı ve kopya çekmeye yönelik tutumun ise bağımlı değişken olarak belirlendiği bir model oluşturulmuştur (Model 1). Bununla birlikte, dişsal akademik kontrol odağının aracı rolünün dikkate alınmadığı alternatif bir model de oluşturulmuş (Model 2) ve bu model dişsal akademik kontrol odağının aracı rolünün dikkate alındığı modelle (Model 1) karşılaştırılmıştır.

YEM analizi sonuçları, dışsal akademik kontrol odağının aracı rolünün dikkate alındığ $1 \quad$ modelin $\quad\left(\chi^{2}(716)=1556.26 ; \quad\right.$ CFI=.935; TLI=.929; RMSEA=.041; SRMR=.055), söz konusu arac1 rolün dikkate alınmadığı modele göre $\quad\left(\chi^{2}(719)=1780.18 ; \quad\right.$ CFI $=.918 ; \quad$ TLI $=.911 ; \quad$ RMSEA=.045; SRMR=.094), araştırmanın verileriyle daha iyi bir uyum sergilediğini göstermiştir $\left.\Delta \chi^{2}(\Delta \mathrm{sd}=3)=223.92, p<.001\right)$. Nitekim alternatif modele ilişkin olarak hesaplanan AIC katsayısı (1982.18), diğer modele ilişkin olarak hesaplanan AIC katsayısından (1764.26) çok daha büyüktür $(\triangle \mathrm{AIC}=217.92>10$, Burnham ve Anderson, 2002). Üstelik Model 1'e ilişkin toplam varyans \%27 olarak hesaplanırken $(p<.01)$, Model 2'ye ilişkin toplam varyans \%6 olarak hesaplanmıştır $(p<.01)$. Bu nedenle Model 2 (alternatif model) dikkate alınmamıştır. Model 1'e ilişkin sonuçlar Tablo 3'te özetlenmiştir. 
Tablo 3. Aracılık Analizi Sonuçları

\begin{tabular}{|c|c|c|c|c|}
\hline Bağımlı Değişken & Bağımsız Değişken & Toplam Etki ${ }^{\mathbf{a}}$ & Doğrudan Etki ${ }^{b}$ & Dolaylı Etki ${ }^{\mathrm{c}}$ \\
\hline Kopya Çekmeye & Akd. Alan Memnuniyeti & $-.14^{* *}[-.22 /-.06]$ & $-.01[-.11 / .09]$ & $-.13^{* *}[-.20 /-.06]$ \\
\hline Yönelik Tutum & Akd. Öz-Yeterlik İnancı & $-.18^{* *}[-.28 /-.08]$ & $.08[-.05 / .21]$ & $-.26^{* *}[-.36 /-.16]$ \\
\hline
\end{tabular}

Dışsal akademik kontrol odağının aracı rolünün sorgulanmasına yönelik olarak gerçekleştirilen YEM analizi sonuçları, akademik alan seçiminden duyulan memnuniyet ile akademik öz-yeterlik inançlarının kopya çekmeye yönelik tutum üzerindeki doğrudan etkilerinin anlamlı olmadığını ancak dişsal akademik kontrol odağı aracılığıyla sağlanan etkilerinin anlamlı olduğunu göstermiştir (Tablo 3). Daha önemlisi, dolaylı etkilerin alt ve üst değerlerinin tümü tutarlı biçimde sıfırdan farklı değerlerdir ki bu, istatistiksel anlamlılığın güvenilir biçimde yorumlanabileceğini göstermektedir. Buna göre, dışsal akademik kontrol odağının hem akademik alan seçiminden duyulan memnuniyetle kopya çekmeye yönelik tutum arasında hem de akademik öz-yeterlik inançlarıyla kopya çekmeye yönelik tutum arasında tam aracı rolü oynadığı belirtilebilir. Dışsal akademik kontrol odağının oynadığı tam aracı rolü Şekil 1'de gösterilmiştir.

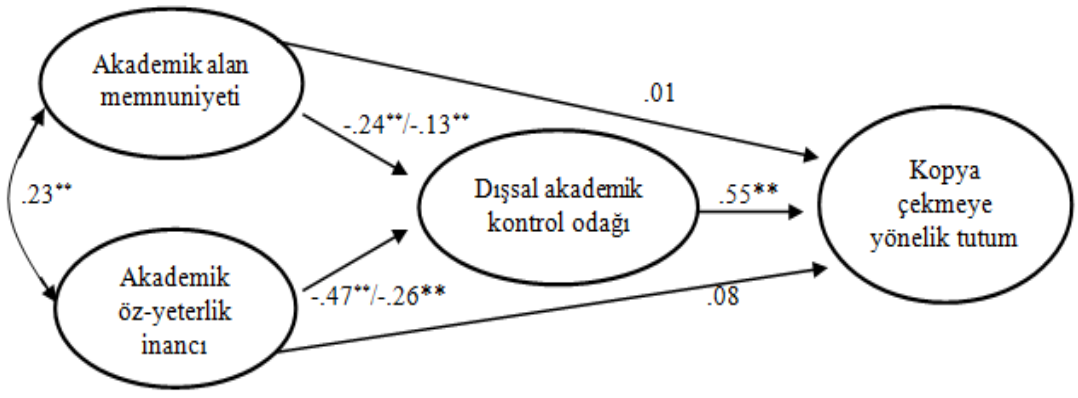

Şekil 1. Dışsal Kontrol Odağının Aracı Rolü

${ }^{* *} p<.01$. Not: Kesiden önceki değerler doğrudan, kesiden sonraki değerler ise dolayı etkilerdir.

Şekil 1'de görüldüğü gibi, akademik alan memnuniyeti ve akademik öz-yeterlik inancı dışsal akademik kontrol odağıyla anlamlı düzeyde ve negatif yönde ilişkilenirken, dışsal akademik kontrol odağ 1 kopya çekmeye yönelik tutumla anlamlı düzeyde ve pozitif yönde ilişkilenmiştir. Ancak akademik alan seçiminden duyulan memnuniyet ve akademik öz-yeterlik inancı kopya çekmeye yönelik tutumla anlamlı düzeyde ilişkilenmemiştir. Oysa her iki bağımsız değişkenin de kopya çekmeye yönelik tutumla, dışsal akademik 
kontrol odağı aracılığıyla sağlanan dolaylı ilişkisi anlamlı düzeyde ve negatif yöndedir.

\section{Tartışma}

\section{Araştırma Değişkenleri Arasındaki İlişkiler}

Korelasyon analizi aracılığıyla elde edilen bulgular, akademik alan seçiminden duyulan memnuniyet ve akademik öz-yeterlik inançlarının dışsal akademik kontrol odağıyla olan ilişkilerinin, içsel akademik kontrol odağıyla olan ilişkilerine kıyasla çok daha güçlü ve negatif yönde olduğunu göstermiştir. YEM analizi aracılığıyla elde edilen bulgular da korelasyon analizi arac1lığıyla bu bağlamda elde edilen bulgularla paraleldir (bkz. Tablo 2, Model 2). Dolayısıyla, korelasyon analizi aracılığıyla elde edilen sonuçların, ölçme hatalarına dayalı olarak ortaya çıkan istatistiksel yapıntılar olmadığı söylenebilir (Sowey ve Petocz, 2017).

Konuyla ilgili alanyazında araştırma değişkenlerinin bir arada ve aynı çalışma kapsamında incelendiği bir araştırmanın bulunmaması, yukarıda özetlenen bulgunun bundan önce gerçekleştirilen araştırmalara atıfla yorumlanmasını güçleştirmektedir. Buna rağmen, araştırmanın bu bulgusu, öğrenim gördüğü alanı seçmekten dolayı duyduğu memnuniyet ile akademik anlamda hissettiği yeterlik düzeyi yüksek olan öğrencilerin, akademik başarı/başarısızlık gibi durumları şans vb. dışsal faktörlere atıfla açıklama eğilimlerinin belirgin biçimde düşük olduğu şeklinde yorumlanabilir. Esasen bu yorum, hem kontrol odağının okula ilişkin memnuniyetle ilişkisinin incelendiği (Huebner, Ash ve Laughlin, 2001) araştırmaların bulgularıyla hem de kontrol odağının öğrencilerin akademik öz-yeterlik inançlarıyla (Sagone ve De Caroli, 2014) ve akademik başarılarıyla (Wood ve ark., 2009) ilişkilerinin incelendiği araştırmaların bulgularıyla tutarlıdır. Nitekim akademik anlamda yaptığı seçimler ve elde ettiği sonuçlar üzerinde fazlaca kontrolünün olmadığına inanan bir öğrencinin, öğrenim gördüğü alanla ilgili seçimine ilişkin olarak da benzer inançlara sahip olabileceği (bu bölüme şans eseri girdiğini ya da bunun kendi seçimi olmadığını düşünme vb.) ile öğrenim gördüğü alanın gerektirdiği akademik görevler ve süreçlerle ilgili yeterliğinin de düşük olabileceğine inanma olasılığının yüksek olabileceğini öne sürmek oldukça mantıklıdır.

Korelasyon analizi bulgularına göre akademik alan memnuniyeti ile akademik öz-yeterlik inancı arasında pozitif yönlü anlamlı ilişki görülmüştür. Alanyazında alan seçiminden duyulan memnuniyet ile akademik öz-yeterlik değişkenlerini ele alan herhangi bir çalışmanın olmaması, söz konusu bulguya 
ilişkin yorumu da sınırlandırmaktadır. Ancak konuyla ilişkilendirilebilecek bir çalışmada (Gündoğan ve Koçak, 2017) okula bağl1lığın akademik öz-yeterliği anlamlı düzeyde yordadığ görülmüştür. İlgili çalışmada öğretmen adaylarının, okula bağlılığ "akademik nedenler" ve "tercih" boyutunda ele aldığı, okula bağlılığın düşük olmasının nedenleri arasında "okulu isteyerek tercih etmeme"yi de gösterdikleri vurgulanmıştır. Başka bir çalışmada ise (Aktaş, 2017) akademik güdülenmenin, akademik öz-yeterliğin \%21'ini açıkladığı görülmüştür. Akademik güdülenmenin, derse ilgi göstermeyi, derse karşı merak ve heyecan duymayı içerdiği (C1la, 2015) göz önünde bulundurulduğunda, söz konusu değişkenin öğrencinin alan seçiminden duyduğu memnuniyeti öncelediği de söylenebilir. Söz konusu çalışmalar dikkate alındığında, alan seçiminden duyulan memnuniyetin akademik öz-yeterlik inancının yordayıcıları arasında olabileceği şeklindeki yorum akla yatkın görünmektedir. Bununla birlikte, akademik alan seçiminden duyulan memnuniyet ve akademik öz-yeterlik inançlarının içsel akademik kontrol odağıyla görece zayıf biçimde ilişkilenmesi dikkat çekicidir. Bunun bir olası nedeni, bundan önceki araştırmalardan farklı olarak (bkz. Huebner ve ark., 2001), bu araştırmada korelasyon analizlerinin gözlemlenen değişkenlerden değil, gizil değişkenlerden hareketle gerçekleştirilmesi olabilir. Bu da sırasıyla, akademik alan seçiminden duyulan memnuniyet ile akademik öz-yeterlik inançlarının dışsal akademik kontrol odağıyla olan ilişkilerinin, içsel akademik kontrol odağıyla olan ilişkilerini baskılamasına yol açabilir. Ayrıca, akademik alan seçiminden duyulan memnuniyet ve akademik öz-yeterlik inançlarının birbiriyle anlamlı düzeyde ve pozitif yönde ilişkilendiği dikkate alındığında, bu değişkenlerin dışsal akademik kontrol odağıyla olan ilişkilerinin, içsel akademik kontrol odağıyla olan ilişkilerine kıyasla daha belirgin olmaları, her iki değişkeninin de kontrol odağıyla olan ilişkilerinin kısmen de olsa eş biçimli bir ilişki örüntüsü sergilediğine işaret etmektedir. Nitekim her iki değişken, kopya çekmeye yönelik tutumla da benzer düzeyde ve yönde, eş biçimli bir ilişki örüntüsü sergilemiştir. Bunun anlamı, öğrenim gördüğü alanı seçmekten dolayı duyduğu memnuniyet ile akademik anlamda hissettiği yeterlik düzeyi yüksek olan öğrencilerin, yalnızca dışsal akademik kontrol odağına sahip olma eğilimlerinin düşük olmadığı, aynı zamanda kopya çekmeye yönelik olumlu tutuma sahip olma eğilimlerinin de düşük olduğudur. Bu yorum, akademik öz-yeterlik inançları ve etik dışı davranışlar (Akyüz, Kesen ve Oğrak, 2016) ile akademik alan seçiminden duyulan memnuniyet ve kopya çekmeye yönelik tutum arasındaki ilişkilerin incelendiği araştırmaların (Manoz-Garcia ve Herrera, 2014; 
Soytürk ve ark., 2015) bulgularıla tutarlıdır.

Dışsal akademik kontrol odağ ile kopya çekmeye yönelik tutum arasındaki güçlü düzeyde ve pozitif yöndeki ilişki $\left(\mathrm{H}_{1}\right)$ ile içsel akademik kontrol odağı ve kopya çekmeye yönelik tutum arasındaki zayıf düzeyde ve negatif ilişki $\left(\mathrm{H}_{2}\right)$ ise bu araştırmanın korelasyon analizi aracılığıyla elde edilen ve $\mathrm{H}_{1}$ ile $\mathrm{H}_{2}$ 'yi doğrulayan diğer önemli bulgularıdır. Öğrencilerin akademik dışsal kontrol odağı ile kopya çekmeye yönelik tutumları arasında görülen pozitif yönlü ilişki alanyazınla tutarlılık göstermekte olup (Coleman ve Mahaffey, 2000; Gallagher, 2010; Pino ve Smith, 2003) söz konusu tutarlılığın, akademik içsel kontrol odağı ile kopya çekmeye yönelik tutum arasında görülen negatif yönlü anlamlı ilişki için de geçerli olduğu görülmüştür (Büyükgöze, 2017; Certel ve ark., 2017; Rinn ve Boazman, 2014). Dişsal akademik kontrol odağının kopya çekmeye yönelik tutumla, içsel akademik kontrol odağının aksi yönünde ve çok daha güçlü biçimde ilişkilenmesi; öğrencilerin elde ettikleri akademik sonuçların nedenlerini daha çok dişsal olaylar ve/veya olgularla açıklamalarının (şans vb.), kopya çekmeyi kabul edilebilir bir davranış olarak algılama eğilimlerini artırma olasılı̆̆ının; söz konusu sonuçların nedenlerini daha çok içsel olgu ve/veya olaylarla açıklamalarının (çaba vb.), kopya çekmeyi kabul edilebilir bir davranış olarak algılama eğilimlerini azaltma olasıl1ğından daha belirgin olduğu şeklinde yorumlanabilir.

Nitekim YEM analizi sonucunda, dışsal akademik kontrol odağının kopya çekmeye yönelik tutumun en güçlü ve tek anlamlı yordayıcısı olduğunun saptanması bu yorumu destekler niteliktedir. Daha önce de değinildiği gibi, bu bulgu, dışsal akademik kontrol odağı ve kopya çekmeye yönelik tutum arasındaki güçlü ilişkinin, diğer değişkenlerin kopya çekmeye yönelik tutumla olan ilişkilerini baskılamasına bağlı olarak ortaya çıkmış olabilir. Söz konusu baskılamanın nedeni ise, dışsal kontrol odağı belirgin olan bireylerin olumsuz hayat deneyimleri karşısında kullanma eğiliminde oldukları stratejilere dayalı olarak açıklanabilir. Nitekim çeşitli bağlamlardaki (sağlık vb.) olumsuz sonuçların/yaşantıların olası nedenlerinin çaba gibi faktörlerden çok, şansızlık gibi faktörlere bağlı olarak açıklanması, dışsal akademik kontrol odağına sahip bireylerin olumsuz yaşantıların etkileriyle başa çıkmada kullandikları tipik stratejilerdir (Reich ve Infurna, 2017). Bunlar; elde edilen olumsuz sonuçların değerlendirilmesi/yeniden değerlendirilmesi ve kişisel hedeflere ulaşmak için farklı ve daha etkili yöntemler kullanma gibi çaba göstermeyi ve sorumluluk almayı gerektiren stratejiler olmamaları nedeniyle, 
bireyler tarafindan olumsuz hayat deneyimlerinin (sevilen birinin ölümü, düşük akademik başarı vb.) psikolojik etkileriyle başa çıkmada etkili ve çaba gerektirmeyen stratejiler olarak algilanabilirler (Specht, Egloff ve Schmukle, 2011).

\section{Dışsal Akademik Kontrol Odağının Aracı Rolü}

Araştırmanın korelasyon analizi ve YEM analizi aracılığıyla elde edilen ve yukarıda tartışılan sonuçları, dışsal akademik kontrol odağının, akademik alan seçiminden duyulan memnuniyet ile kopya çekmeye yönelik tutum arasındaki ve akademik öz-yeterlik inançlarıyla kopya çekmeye yönelik tutum arasındaki ilişkilerde, aracı değişken rolü oynama potansiyeli içerdiğini ortaya koymuştur. Ayrıntılı olarak, YEM analizi aracılığıyla elde edilen sonuçlar, akademik alan seçiminden duyulan memnuniyet ile akademik öz-yeterlik inançlarının dışsal kontrol odağını güçlü düzeyde ve negatif yönde yordadığını, dışsal akademik kontrol odağının ise kopya çekmeye yönelik tutumu anlamlı düzeyde yordayan tek değişken olduğunu göstermiştir. Bağımsız değişkenlerin aracı değişkenle, aracı değişkeninin ise bağımlı değişkenle ilişkili olması, aracılık analizleri için son derece önemli bir koşuldur (MacKinnon, Fairchild ve Fritz, 2007). Diğer taraftan, bağımsız değişkenlerin bağımlı değişkenle anlamlı düzeyde ilişkilenmesi, aracılık analizleri için mutlak bir koşul değildir (MacKinnon ve ark., 2007). İçsel akademik kontrol odağının, söz konusu değişkenler arasındaki ilişkilerde neden aracı rolü oynama potansiyelini içermediği, dışsal akademik kontrol odağının yukarıda detaylı biçimde tartışılan, baskılama rolüne bağlı olarak açıklanabilir.

Nitekim aracılık analizi aracılığıyla elde edilen sonuçlar, hem akademik alan seçiminden duyulan memnuniyetin hem de akademik öz-yeterlik inançlarının kopya çekmeye yönelik tutum üzerindeki doğrudan etkilerinin anlamlı olmadığını ancak dışsal akademik kontrol odağı aracılığıyla sağlanan dolaylı etkilerinin anlamlı olduğunu göstermiştir. Ayrıca sonuçlar bundan önce gerçekleştirilen ve benzer değişkenlerin incelendiği araştırmalardan elde edilenlerle tutarlı biçimde (Büyükgöze, 2017; Rinn ve Boazman, 2014), öğrencilerin söz konusu nedenleri dışsal faktörlerle açıklama eğilimleri ne ölçüde yüksekse, kopya çekmeye yönelik tutumlarının o ölçüde olumlu olduğunu da göstermiştir (bkz. Şekil 1).

Aracılık analizi aracılığıyla elde edilen sonuçlar birlikte ele alındığında, bunların; hem akademik alan seçiminden duyulan memnuniyetin hem de akademik öz-yeterlik inançlarının kopya çekmeye yönelik tutum üzerindeki 
negatif etkilerinin, dışsal akademik kontrol odağı aracılığıyla sağlandığını gösteren önemli bir bulguyu ortaya koyduğu söylenebilir. Bu bulgu, öğrenim gördüğü alana yönelik hissettiği memnuniyet düzeyi ile akademik anlamda hissettiği yeterlik düzeyi yüksek olan öğrencilerin kopya çekmeyle ilgili olumsuz tutumlara sahip olmalarının, akademik açıdan elde ettikleri sonuçların (ders başarısı vb.) nedenlerini şans, kader gibi dişsal faktörlerle açıklama eğilimlerinin düşük olmasına bağlı olduğu şeklinde yorumlanabilir.

Konuyla ilgili alanyazında, dışsal akademik kontrol odağının söz konusu değişkenler arasındaki aracı rolünün incelendiği bir araştırma bulunmaması nedeniyle, bu bulgunun bundan önceki araştırmaların bulgularıyla ilişkilendirilmesi mümkün değildir. Buna karşın, araştırmanın söz konusu bulgusunun, bu araştırmadaki değişkenlerden bazıları arasındaki ilişkilerin farklı bağlamlarda ve farklı analiz teknikleriyle incelendiği araştırmaların bulgularıyla, kısmen de olsa tutarlı olduğu ifade edilebilir (Soytürk ve ark., 2015; Yeşilyurt, 2014). Daha önemlisi, bu bulgunun, bundan önceki araştırmaların bulguları arasındaki çelişkinin (Çetin, 2007; Soytürk ve ark., 2015), öğrencilerin akademik alan seçiminden duydukları memnuniyetle kopya çekmeye yönelik tutumları arasındaki ilişkide aracı rolü oynama potansiyeli içeren değişkenlerin dikkate alınmamasından kaynaklandığı öngörüsünü (bkz. 2.2. Akademik Alan Memnuniyeti başlı̆̆ 1 altındaki açıklamalar) önemli ölçüde desteklediği de ifade edilebilir.

\section{Sonuç}

$\mathrm{Bu}$ araştırmanın bulguları doğrultusunda iki önemli sonuç çıkarılabilir. Birincisi, üniversite öğrencilerinin öğrenim gördükleri alanlara ilişkin olarak yaptıkları seçimlerinden dolayı duydukları memnuniyetin, akademik anlamda sahip olduklarına inandıkları yeterliğin ve akademik açıdan elde ettikleri sonuçları içsel ya da dışsal referanslara atıfla açıklamalarının, hem birbirleriyle hem de kopya çekmeye yönelik tutumlarıyla anlamlı düzeyde ve seçici biçimde ilişkilendiği ve söz konusu ilişkilerin, bu araştırmanın örneklemi kapsamında, cinsiyet gibi demografik değişkenlerin etkilerinden bağımsız biçimde yorumlanabildiğidir. İkincisi ve daha önemlisi, öğrencilerin hem alan seçiminden dolayı duydukları memnuniyetin hem de akademik açıdan sahip olduklarına inandıkları yeterliğin kopya çekmeye yönelik tutumlarıyla olan negatif yöndeki ilişkilerinin, tümüyle, akademik açıdan elde ettikleri sonuçları daha az ölçüde dışsal referanslara atıfla açıklamalarına bağlı olduğudur.

$\mathrm{Bu}$ araştırmada elde edilen bulguların, akademik açıdan yaygın bir 
usulsüzlük biçimi olan kopya çekmenin, öğrenciler tarafından olumlu bir davranış biçimi olarak algılanmasının önlenmesine ya da en azından, söz konusu algıların olumsuz etkilerinin azaltılmasına yönelik önemli doğurgular içerdiği söylenebilir. Ayrıntılı olarak araştırmanın bulguları, akademik alan seçiminden duyulan memnuniyet ve akademik öz-yeterlik inançlarının dışsal akademik kontrol odağıyla, içsel akademik kontrol odağına kıyasla, görece daha güçlü ve negatif yönde ilişkilendiğini göstermiştir. Bulgular ayrıca, akademik alan seçiminden duyulan memnuniyet ve akademik öz-yeterlik inançlarının kopya çekmeye yönelik tutumla da anlamlı düzeyde ve olumsuz yönde ilişkilendiğini göstermiştir. Dolayısıyla, genelde üniversitelerdeki ilgili bölümlerin yöneticilerinin, özelde ise öğretim elemanlarının, öğrencilerin akademik alan seçiminden duydukları memnuniyeti ve akademik öz-yeterlik inançlarını artırmaya yönelik etkili girişimleri, onların dışsal akademik kontrol odağını benimseme olasılığını azaltabilir. Bu da sırasıyla, öğrencilerin kopya çekmeye yönelik olumsuz tutum geliştirmelerine yol açarak, akademik başarının çok daha objektif ve etik bir görünüm içermesine katkı sağlayabilir.

Ayrıntılı olarak, akademik alan seçiminden duyulan memnuniyetin artırılması amacıyla üniversitelerde, öğrencilerin öğrenim gördükleri alanların hem akademik hem de meslekî anlamda içerdiği olanakların ele alındığı kariyer günleri vb. etkinlikler düzenlenebileceği gibi, bu konularla ilgili bilgilendirme süreçlerine süreklilik kazandırmak için danışmanlık ve kariyer planlama merkezleri de kurulabilir. Türkiye'de meslekî rehberlik ve kariyer danışmanlığı hizmetlerinin ortaöğretim kurumlarında yeterli düzeyde olmadığı düşünüldügünde (Çivildağ, Günbayı ve Yörük, 2015; Yeşilyaprak, 2010), bu önerilerin yalnızca üniversiteler açısından değil, aynı zamanda liseler açısından da dikkate alınmasının, ekonomik kalkınmada son derece önemli bir faktör olan insan kaynağının (Yılmaz ve Danışoğlu, 2017) etkili biçimde değerlendirilebilmesi için son derece önemli olduğu ifade edilebilir. Esasen bu ve benzeri uygulamalar, öğrencilerin akademik öz-yeterlik inançlarının da olumlu yönde etkilenmesine katkı sağlayabilir. Bu noktada değinilmesi gereken önemli bir konu, öğrencilerin akademik öz-yeterlik inançlarının gerçekçi bir zemine dayalı olmasının gerekli olduğudur. Nitekim gerçekçi olmayan özyeterlik inançları, öğrencilerin akademik gelişimini olumsuz yönde etkileyebilir (Kruger ve Dunning, 1999). Üstelik kopya gibi etik olmayan yollarla elde edilen akademik başarı, öğrencilerin akademik öz-yeterlik inançlarını gerçek dışı biçimde artırabilir (arkadaşları ve öğretim elemanları tarafından takdir edilme vb.) ve bu da sırasıyla onları kopya çekmeye daha fazla yönelterek, 
olumsuz bir geri besleme döngüsüne yol açabilir. Dolayısıyla, öğrencilerin akademik açıdan gerçekçi öz-yeterlik inançları geliştirmelerinin sağlanmasına yönelik uygulamalar (süreç odaklı ölçme-değerlendirme yaklaşımlarına dayalı olarak verilen gerçekçi dönüt ve bu doğrultuda yapılan düzeltme uygulamaları vb.), onların etik hassasiyetlerini artırarak, söz konusu olumsuz geri besleme döngüsünün kırılmasını sağlayabilir.

$\mathrm{Bu}$ araştırmanın bulguları, akademik alan seçiminden duyulan memnuniyetin ve akademik öz-yeterlik inançlarının kopya çekmeye yönelik tutumla olan negatif yöndeki ilişkilerinin, akademik dışsal kontrol odağıyla olan negatif yöndeki ilişkileri aracılığıyla sağlandığını göstermiştir. Bunun anlamı, öğrencilerin akademik alan seçiminden dolayı duydukları memnuniyetle akademik öz-yeterlik inançlarına yönelik olarak yukarıda değinilen girişimlerde/uygulamalarda, öğrencilerin dışsal akademik kontrol odaklarının dikkate alınmasının da gerekli olduğudur. Buna göre, öğretim elemanlarının, öğrencilerinin akademik konularda elde ettikleri sonuçları (örneğin sınav sonuçları) nasıl açıkladıklarını dikkate almaları gerektiği söylenebilir. Öğrencilerin akademik kontrol odaklarının anlaşılması amacıyla çeşitli ölçme araçlarının yanında, soru-cevap, örnek olay incelemesi gibi birçok yöntem de kullanılabilir. Öğretim elemanları, bu ve benzeri yöntemlerle öğrencilerinin akademik kontrol odaklarını güvenilir biçimde tanılayabilir ve öğrencilerin bu bağlamda öne sürdükleri gerekçelerin mantığının sorgulanmasına yönelik olarak gerçekleştirdikleri yansıtıcı düşünme gibi etkinlikler aracılığıyla da onların akademik sonuçları değerlendirirken kullandıkları düşünce yapılarına (Dweck, 2006) ilişkin kapsamlı bir farkındalık oluşturmalarına olanak sağlayabilirler. Böyle bir farkındalığın oluşturulması amacıyla, üniversitelerdeki derslerin öğretim programlarının eğitim durumları boyutunda, akademik kontrol odağı önemli bir bireysel farklılık değişkeni olarak dikkate alınabilir ve yansıtıcı düşünme, eleştirel düşünme vb. etkinlikler aracılığıyla da, hem öğrencilerin elde ettikleri akademik sonuçları (düşük ders başarısı vb.) açıklamada kullandıkları şemalara hem de bu şemaların kişisel ve/veya meslekî amaçlarıyla ilgili kararları nasıl etkilediğine yönelik kapsamlı bilişsel değerlendirmeler yapmaları sağlanabilir. Bu da sırasıyla, öğrencilerin çabanın önemini daha fazla takdir etme eğilimlerini artırırken, kopya çekme gibi etik dışı davranışlara yönelme ve/veya bu araştırmanın bulgularının da gösterdiği gibi, böyle davranışları hoş görme eğilimlerini azaltabilir.

Yukarda değinilen önemli doğurgularına rağmen, bu araştırma; (a) 
örnekleminin yalnızca eğitim, fen-edebiyat, mühendislik ve ilahiyat fakültelerinin bazı bölümlerinde öğrenim gören öğrencilerden oluşması; (b) örneklem büyüklüğünün görece küçük olması $(n=715)$; (c) elde edilen sonuçların nedensellik çıkarımına dayalı biçimde yorumlanmasına imkân veren bir yöntemden hareketle gerçekleştirilmemiş olması ve (d) akademik alan seçiminden duyulan memnuniyetle akademik öz-yeterlik inançları arasındaki olası etkileşimin, kopya çekmeye yönelik tutum üzerindeki etkisinin, dışsal akademik kontrol odağı aracılığıyla sağlanıp sağlanmadığını incelememiş olması gibi bazı sınırlılıklara sahiptir. Dolayısıyla, bu araştırmada elde edilen bulgular gelecekte yapılacak araştırmalarda dikkatle yorumlanmalıdır.

Gelecekte yapılacak araştırmaların; (a) farklı fakültelerin (iletişim, spor bilimleri vb.), farklı bölümlerinde (güzel sanatlar eğitimi, kimya vb.) öğrenim gören öğrencileri de içermesi; (b) örneklemlerinin daha fazla sayıda öğrenciden oluşması ( $\mathrm{n}>1000$ ); (c) deneysel ya da boylamsal desenlerden (çapraz panel deseni vb.) hareketle gerçekleştirilmesi ve (d) akademik alan seçiminden duyulan memnuniyetle akademik öz-yeterlik inançları arasındaki etkileşimin kopya çekmeye yönelik tutum üzerindeki olası etkisini de incelemesi, bu konuda daha kapsamlı bulgular elde edilmesine yol açabilir. Bu araştırmalar arac1lığıyla elde edilecek bulgular, okul gibi akademik ortamlarda belirgin bir problem durumu olan kopya çekme davranışının (Polat, 2017) engellenmesine ya da azaltılmasına yönelik önemli katkılar sağlayabilir.

\section{Kaynakça}

Ahmadi, A. (2012). Cheating on exams in the Iranian EFL context. Journal of Academic Ethics, 10, 151-170.

Doi: $10.1007 / \mathrm{s} 10805-012-9156-5$

Akın, A. (2007). Akademik Kontrol Odağı Ölçeği: Geçerlik ve güvenirlik çalışması. Çukurova Üniversitesi Eğitim Fakültesi Dergisi, 34(3), 9-17.

Akın, A., Odabaşı, Ş. ve Özçelik, B. (2015). Akademik Branş Memnuniyeti Ölçeği Türkçe formunun geçerlik ve güvenirlik çalışması. International Journal of Social Science, 36, 1-7.

Aktaş, H. (2017). Akademik güdülenme ile akademik özyeterlik arasındaki ilişki: ilahiyat fakültesi öğrencileri üzerine ampirik bir araștırma. İnsan ve Toplum Bilimleri Araştırmaları Dergisi, 6(3), 1376-1398.

Akyüz, B., Kesen, M. ve Oğrak, A. (2016). Örgütsel güven ve akademik özyeterlik algısının genel sinizm ve etik dışı davranışlara etkisi. Çankırı Karatekin Üniversitesi Sosyal Bilimler Enstitüsü Dergisi, 7(1), 85-106.

Alarape, A. I. ve Onakoya, A. Y. (2003). Correlates of examination cheating behavior among university students. IFE Psychologia: An International Journal, 11, 7179.

Anderman, E. M. ve Murdock, T. B. (Ed.). (2007). Psychology of academic cheating. 
Burlington, MA: Elsevier Academic Press.

Arbuckle, J. R. (2012). AMOS users guide version 21.0. Chicago, IL: Marketing Department, SPSS Incorporated.

Ay, M. F. ve Çakmak, A. (2015). Kopya Çekmeye Yönelik Tutum Ölçeğinin geliştirilmesi: Geçerlilik ve güvenirlik çalışması. Atatürk Üniversitesi İlahiyat Fakültesi Dergisi, 43, 140-155.

Bandura, A. (1997). Self-efficacy: The exercise of control. New York: Freeman.

Benmansour, N. (2000). Motivation, satisfaction, success attributions and cheating among high school students in Morocco. Mediterranean Journal of Educational Studies, 5(2), 83-102.

Bozdoğan, A. E. ve Öztürk, Ç. (2008). Öğretmen adayları neden kopya çeker? Illkögretim Online, 1, 141-149.

Burnham, K. P. ve Anderson, D. R. (2002). Model selection and multimodel inference: A practical information theoretical approach. New York: Springer-Verlag.

Büyükgöze, H. (2017). Öğretmen adaylarının akademik sahtekarlık eğilimlerinde özyeterlik ve akademik kontrol odağının rolü. MCBÜ Sosyal Bilimler Dergisi, 15(1), 802-822.

Calabrese, R. L. ve Cochran J. T. (1990). The relationship of alienation to cheating among sample of American adolescents. Journal of Research and Development in Education, 23(2), 65-72.

Certel, Z., Bahadır Z., Saracaloğlu, S. ve Varol, R. (2017). Beden eğitimi öğretmen adaylarının kopya çekme eğilimleri ve akademik kontrol odaklarının incelenmesi. Ĕ̈itim ve Öğretim Araştırmaları Dergisi, 6(2), 259-271.

C1la, M. S. (2015). Anadolu lisesi 9. ve 10. sınıf öğrencilerinin akademik başarlartnın, akademik özyeterlik, mükemmeliyetçilik ve akademik güdülenmeden yordanması. Yayımlanmamış yüksek lisans tezi, Gazi Üniversitesi Eğitim Bilimleri Enstitüsü.

Coleman, N. ve Mahaffey, T. (2000). Business student ethics: Selected predictors of attitudes toward cheating. Teaching Business Ethics, 4, 121-136. Doi: $10.1023 / \mathrm{A}: 1009855128668$

Çetin, Ş. (2007). Üniversite öğrencilerinin kopya çekme davranışlarının farklı değişkenler açısından incelenmesi. Millî Ĕ̈itim Dergisi, 175, 129-142.

Çivildağ, A., Günbayı, İ. ve Yörük, T. (2015). Mesleki rehberlik çalışmalarına ilişkin nitel bir analiz: Antalya örneği. Uluslararası Sosyal Araştırmalar Dergisi, 38(8), 573-594.

Daum, T. L. ve Wiebe, G. (2003). Locus of control, personal meaning, and self-concept before and after an academic critical incident. Yayımlanmamış yüksek lisans tezi, Trinity Western University.

DeVellis, R. F. (2017). Scale development: Theory and applications (4. bask1). Newbury Park, CA: Sage Publications.

Diener, E., Emmons, R., Larsen, R. ve Griffin, S. (1985). The satisfaction with life scale. Journal of Personality Assessment, 49, 1105-1117.

DiStefano, C., Liu, J., Jiang, N. ve Shi, D. (2017). Examination of the weighted root mean square residual: Evidence for trustworthiness? Structural Equation Modeling: A Multidisciplinary Journal, 25(3), 453-466.

Douglas, S. P. ve Craig, C. S. (2007). Collaborative and iterative translation: An 
alternative approach to back translation. Journal of International Marketing, $15,30-43$.

Durmuşçelebi, M. (2011). Lise öğrencilerinin ve öğretmen adaylarının kopya çekme davranışlarına ilişkin görüşleri. Kuram ve Uygulamada Eğitim Yönetimi, 17(1), 77-97.

Dweck, C. S. (2006). Mindset: The new psychology of success. New York: Random House.

Elias, R. Z. (2009). The impact of anti-intellectualism attitudes and academic selfefficacy on business students' perceptions of cheating. Journal of Business Ethics, 86, 199-209.

Doi: $10.1007 / \mathrm{s} 10551-008-9843-8$

Er, K. O. ve Gürgan, U. (2011). Öğretmen adaylarının öz-yeterlilik algıları ve kopya çekmeye ilişkin tutumları arasındaki ilişki. Balıkesir Üniversitesi Sosyal Bilimler Enstitüsü Dergisi, 14(26), 1-18.

Eraslan, A. (2011). Matematik öğretmeni adayları ve kopya: Hiç çekmedim desem yalan olur! Eğitim ve Bilim, 36(160), 52-64.

Erdoğan, D. G. ve Arsal, Z. (2015). The adaptation of academic major scale to Turkish: The validity and reliability study. International Journal of Human Sciences, 12(1), 966-974.

Ferguson, C. J. (2009). An effect size primer: A guide for clinicians and researchers. Professional Psychology: Research and Practice, 40(5), 532-538.

Ferrando, P. J. ve Lorenzo-Seva, U. (2017). Program FACTOR at 10: Origins, development and future directions. Psicothema, 29, 236-240.

Ferrando, P. J. ve Lorenzo-Seva, U. (2018). Assessing the quality and appropriateness of factor solutions and factor score estimates in exploratory item factor analysis. Educational and Psychological Measurement, 78(5), 762-780.

Field, A. (2009). Discovering statistics using SPSS. London: Sage.

Fraenkel, J. R., Wallen, N. E. ve Hyun, H. H. (2012). How to design and evaluate research in education. New York: McGraw-Hill.

Furukawa, R., Driessnack, M. ve Colclough, Y. (2014). A committee approach maintaining cultural originality in translation. Applied Nursing Research, 27, 144146.

Gallagher, J. A. (2010). Academic integrity and personality. Yayımlanmamış yüksek lisans tezi, California State University.

Gündoğan, A. ve Koçak, A. (2017). Öğretmen adaylarının okul iklimi algıları ile akademik öz-yeterlik inançları arasındaki ilişkinin incelenmesi. Sakarya University Journal of Education, 7(3), 639-657.

Hans, T. (2000). A meta-analysis of the effects of adventure programming on locus of control. Journal of Contemporary Psychotherapy, 30(1), 33-60.

Hayes, A. F. ve Scharkow, M. (2013). The relative trustworthiness of inferential tests of the indirect effect in statistical mediation analysis: Does method really matter? Psychological Science, 24(10), 1918-1927.

Huebner, E. S., Ash, C. ve Laughlin, J. E. (2001). Life experiences, locus of control, and school satisfaction in adolescence. Social Indicators Research, 55(2), 167183.

İskender, M. ve Akın, A. (2010). Social self-efficacy, academic locus of control, and internet addiction. Computers \& Education, 54, 1101-1106. 
Jerusalem, M. ve Schwarzer, R. (1981). Fragebogen zur Erfassung von "Selbstwirksamkeit". R. Schwarzer, (Ed.), Skalen zur Befindlichkeit und Persönlichkeit içinde (15-28), Berlin: Freie Universitaet, Institut für Psychologie.

Kaymakcan, R. (2002). İlahiyat öğrencilerinin kopya çekmeye karşı yaklaşımları. Sakarya Üniversitesi Illahiyat Fakültesi Dergisi, 5, 121-138.

Kelley, T. L. (1935). Essential traits of mental life, Harvard studies in education (26. cilt). Cambridge, MA: Harvard University Press.

Kerkvliet, J. ve Sigmund, C. L. (1999). Can we control cheating in the classroom? The Journal of Economic Education, 30(4), 331-343.

Kline, R. B. (2011). Principles and practice of structural equation modeling. New York: Guilford Press.

Kruger, J. ve Dunning, D. (1999). Unskilled and unaware of it: How difficulties in recognizing one's own incompetence lead to inflated self-assessments. Journal of Personality and Social Psychology, 77(6), 1121-1134.

Ledesma, R. G. (2011). Academic dishonesty among undergraduate students in a Korean University. Research in World Economy, 2(2), 25-35.

Lin, C. S. ve Wen, L. M. (2007). Academic dishonesty in higher education: A nationwide study in Taiwan. Higher Education, 54(1), 85-97.

Lupton, R. A., Chapman, K. J. ve Weiss, J. E. (2000). International perspective: A cross-national exploration of business students' attitudes, perceptions, and tendencies toward academic dishonesty. Journal of Education for Business, 75(4), 231-235.

Doi: $10.1080 / 08832320009599020$

Lüle Mert, E. (2012). Temel işlevi bilim insanı yetiştirmek olan bazı bölümlerde kopya. Turkish Studies- International Periodical for The Languages, Literature and History of Turkish or Turkic, 7(3), 1813-1829.

MacKinnon, D. P., Fairchild, A. J. ve Fritz, M. S. (2007). Mediation analysis. Annual Review of Psychology, 58, 593-614.

Maio, G. R. ve Haddock, G. (2010). The psychology of attitudes and attitude change. London: SAGE.

Marsden, H., Carroll, M. ve Neill, J. T. (2005). Who cheats at university? A self-report study of dishonest academic behaviours in a sample of Australian University students. Australian Journal of Psychology, 57(1), 1-10.

McCabe, D. L. (2005). Cheating among college and university students: A North American perspective. International Journal for Educational Integrity, 1(1), $1-11$.

Doi: http://dx.doi.org/10.21913/IJEI.v1i1.14

McCabe, D. L., Feghali, T. ve Abdallah, H. (2008). Academic dishonesty in the middle east: Individual and contextual factors. Research in Higher Education, 49, 451-467.

McCabe, D. L., Trevino, L. K. ve Butterfield, K. D. (2001). Cheating in academic institutions: A decade of research. Ethics and Behavior, 11(3), 219-232.

McIlveen, P., Beccaria, G. ve Burton, L. J. (2013). Beyond conscientiousness: Career optimism and satisfaction with academic major. Journal of Vocational Behavior, 83(3), 229-236.

Doi: $10.1016 /$ j.jvb.2013.05.005 
Munoz-Garcia, A. ve Aviles Herrera, M. J. (2014). Effects of academic dishonesty on dimensions of spiritual well-being and satisfaction: A comparative study of secondary school and university students. Journal of Assessment and Evaluation in Higher Education, 39(3), 349-363.

Doi: 10.1080/02602938.2013.832729

Murdock, T., Hale, N. ve Weber, M. J. (2001). Predictor of cheating among early adolescents: Academic and social motivations. Contemporary Educational Psychology, 26(1), 96-115.

Doi: https://doi.org/10.1006/ceps.2000.1046

Nauta, M. M. (2007). Assessing college students' satisfaction with their academic majors. Journal of Career Assessment, 15, 446-462.

Nunn, G. D. ve Nunn, S. J. (1993). Locus of control and school performance: Some implications for teachers. Education, 113(4), 636-641.

O’Rourke, J., Barnes, J., Deaton, A., Fulks, K., Ryan, K. ve Rettinger, D. A. (2010). Imitation is the sincerest form of cheating: The influence of direct knowledge and attitudes on academic dishonesty. Ethics and Behavior, 20, 47-64.

Özden, M., Özden Özdemir, D. ve Biçer, B. (2015). Akademik usulsüzlük: sınıf öğretmeni adaylarının deneyimleri. Dumlupınar Üniversitesi Sosyal Bilimler Dergisi, 45, 130-143.

Özyurt, Y. ve Eren, A. (2014). Fen bilgisi öğretmen adaylarının öğretmenlik mesleğine ve kopya çekmeye yönelik tutumlarının görünümü. Bartın Üniversitesi Ĕ̆itim Fakültesi Dergisi, 3(1), 78-101.

Permatasari, D. P. (2017, Ekim). Correlation between self-efficacy and cheating behavior on vocational high school students. $8^{\text {th }}$ International Conference on Language, Innovation, Culture, and Education' da sunulan bildiri, London.

Pessoa, L. (2008). On the relationship between emotion and cognition. Nature Reviews Neuroscience, 9, 148-158.

Phelps, E. A. (2006). Emotion and cognition: Insights from studies of the human amygdala. Annual Review of Psychology, 57, 27-53.

Pino, N. W. ve Smith, W. L. (2003). College students and academic dishonesty. College Student Journal, 37, 490-500.

Polat, M. (2017). Türkiye'de öğrenciler neden kopya çeker? Bir meta-sentez çalışması. Eğitim Bilimleri Araştırmaları Dergisi, Uluslararası e-Dergi, 7(1), 223-242.

Reich, J. W. ve Infurna, F. J. (Ed.). (2017). Perceived control: Theory, research, and practice in the first 50 years. New York: Oxford University Press.

Richardson, J. T. E. (2011). Eta squared and partial eta squared as measures of effect size in educational research. Educational Research Review, 6(2), 135-147.

Rinn, A. N. ve Boazman, J. (2014). Locus of control, academic self-concept, and academic dishonesty among high ability college students. Journal of the Scholarship of Teaching and Learning, 14(4), 88-114.

Roig, M. ve DeTommaso, L. (1995). Are college cheating and plagiarism related to academic dishonesty. Psychological Reports, 77, 691-698.

Rotter, J. B. (1966). Generalized expectancies for internal versus external control of reinforcement. Psychological Monographs: General and Applied, 80(1), 1-28.

Rotter, J. B. (1990). Internal versus external control of reinforcement: A case history of a variable. American Psychologist, 45, 489-493. 
Sagone, E. ve De Caroli, M. E. (2014). Locus of control and academic self-efficacy in university students: The effects of self-concepts. Procedia-Social and Behavioral Sciences, 114, 222-228.

Schunk, D. H. (1991). Self-efficacy and academic motivation. Educational Psychologist, 26, 207-231.

Semerci, Ç. (2004). Tıp fakültesi öğrencilerinin kopya çekmeye ilişkin tutum ve görüşleri. Fırat Üniversitesi Sağllk Bilimleri Dergisi, 18(3), 139-146.

Seven, M. A. ve Engin, A. O. (2008). Eğitim fakültesi öğrencilerinin kopya çekmeye duydukları ihtiyaç ve kopya çekme sebepleri. Atatürk Üniversitesi Sosyal Bilimler Enstitüsü Dergisi, 1, 121-136.

Shi, D., Maydeu-Olivares, A. ve Rosseel, Y. (2020). Assessing fit in ordinal factor analysis models: SRMR vs. RMSEA. Structural Equation Modeling: A Multidisciplinary Journal, 27, 1-15.

Shin, D. C. ve Johnson, D. M. (1978). Avowed happiness as an overall assessment of the quality of life. Social Indicators Research, 5, 474-492.

Sowey, E. ve Petocz, P. (2017). A panorama of statistics: Perspectives, puzzles and paradoxes in statistics. London: John Wiley \& Sons.

Soytürk, M., Tepeköylü Öztürk, Ö., Topuz, E. ve Yetim, H. (2015). Beden eğitimi öğretmen adaylarının benlik saygıları ile kopya çekmeye ilişkin tutumları arasındaki ilişkinin incelenmesi. CBÜ BESYO örneği. Uluslararası Spor, Egzersiz ve Antrenman Bilimi Dergisi, 1(1), 20-30.

Specht, J., Egloff, B. ve Schmukle, S. C. (2011). The benefits of believing in chance or fate: External locus of control as a protective factor for coping with the death of a spouse. Social Psychological and Personality Science, 2(2), 132-137.

Starovoytova, D. ve Namango, S. (2016). Factors affecting cheating-behavior at undergraduate-engineering. Journal of Education and Practice, 7(31), 66-82.

Tabachnick, B. G. ve Fidell, L. S. (2013). Using multivariate statistics. Boston: Pearson.

Topçu, Y. ve Uzundumlu, A. S. (2011). Yüksek öğretimde öğrencilerin kopya çekme motivasyonu ile ilgili tutum ve davranışları. Uluslararası Insan Bilimleri Dergisi, 8(2), 303-313.

Uguak, U. A., Habibah, Bt. E., Jegak, U. ve Turiman, S. (2007). The influence of causal elements of locus of control on academic achievement satisfaction. Journal of Instructional Psychology, 34(2), 120-128.

Umaru, Y. (2013). Moderating role of academic self-efficacy on school achievement and cheating among senior secondary school students. Gender \& Behavior, $11(1), 5168-5174$.

Ünlü, H. ve Eroğlu, C. (2012). Beden eğitimi öğretmen adaylarının kopya çekmeye yönelik tutumları. Spormetre: Beden Eğitimi ve Spor Bilimleri Dergisi, 3, 101106.

Wiers-Jenssen, J., Stensaker, B. ve Grøgaard, J. B. (2002). Student satisfaction: Towards an empirical deconstruction of the concept. Quality in Higher Education, 8(2), 183-195.

Wood, A. M., Saylor, C. ve Cohen, J. (2009). Locus of control and academic success among ethnically diverse baccalaureate nursing students. Nursing Education Research, 30, 290-294.

Wood, R. E. ve Locke, E. A. (1987). The relation of self-efficiency and grade goals 
to academic performance. Educational and Psychological Measurement, 47, 1013-1024.

Doi: $10.1177 / 0013164487474017$

Yan Nora, W. L. ve Chen Zang, K. (2010). Motives of cheating among secondary students: The role of self-efficacy and peer influence. Asia Pacific Education Review, 11, 573-584.

Yangın, S. ve Kahyaoğlu, M. (2009). İlköğretim öğretmen adaylarının kopya çekmeye yönelik tutum ve görüşleri. Balıkesir Üniversitesi Sosyal Bilimler Enstitüsü Dergisi, 12(21), 46-55.

Yeşilyaprak, B. (2010). Ĕgitimde rehberlik hizmetleri (10. baskı). Ankara: Nobel Yayın ve Dağıtım.

Yeşilyurt, E. (2014). Academic locus of control, tendencies towards academic dishonesty and test anxiety levels as the predictors of academic self-efficacy. Educational Sciences: Theory \& Practice, 14(5), 1945-1956.

Doi: 10.12738/estp.2014.5.1841

Yılmaz, M., Gürçay, D. ve Ekici, G. (2007). Akademik öz yeterlik ölçeğinin Türkçe’ye uyarlanması. Hacettepe Üniversitesi Eğitim Fakültesi Dergisi, 33, 253-259.

Yılmaz, Z. ve Danışoğlu, F. (2017). Ekonomik kalkınmada beşeri sermayenin rolü ve Türkiye'de beşeri kalkınmanın görünümü olarak insani gelişim endeksi. Dumlupınar Üniversitesi Sosyal Bilimler Dergisi, 51, 117-147.

Zajacova, A., Lynch, S. M. ve Espenshade, T. J. (2005). Self-efficacy, stress, and academic success in college. Research in Higher Education, 46, 677-705. Doi: 10.1007/s11162-004-4139-z. 